\title{
Functional relationships between vegetation, channel morphology, and flow efficiency in an alluvial (anabranching) river
}

\author{
John D. Jansen ${ }^{1,2}$ and Gerald C. Nanson ${ }^{3}$ \\ Received 3 January 2010; revised 31 August 2010; accepted 21 September 2010; published 14 December 2010.
}

[1] Water and sediment flux interactions are examined in Magela Creek, an alluvial (anabranching) sand bed river in the northern Australian tropics. Dense riparian vegetation stabilizes the channels and floodplains thereby preventing erosional instability at flow depths up to 6.2 times bankfull and discharges up to 15 times bankfull. Narrow anabranching channels characterize $>92 \%$ of the alluvial reach and transport bed load more efficiently than short reaches of wide single-channels, yet overall $29 \pm 12 \%$ of the bed load is sequestered and the average vertical accretion rate is $0.41 \pm 0.17 \mathrm{~mm} \mathrm{yr}^{-1}$ along the $12 \mathrm{~km}$ study reach. The most effective discharge for transporting sediment $\left(40-45 \mathrm{~m}^{3} \mathrm{~s}^{-1}\right)$ is consistent at all 5 stations (10 channels) examined and is equivalent to the channel-forming discharge. It has an average recurrence interval of 1.01 years, occurs for an exceptionally long portion (13-15\%) of the annual flow duration, and averages a remarkable 2.1 times bankfull. The high flow efficiency (i.e., bed load transport rate to stream power ratio) of the anabranches is facilitated by low width/depth channels with banks reinforced by vegetation. Colonnades of bank top trees confine high-velocity flows overbed (i.e., over the channel bed) at stages well above bankfull. At even larger overbank flows, momentum exchange between the channels and forested floodplains restrains overbed velocities, in some cases causing them to decline, thereby limiting erosion. Magela Creek exhibits a complicated set of planform, cross-sectional and vegetative adjustments that boost overbed velocities and enhance bed load yield in multiple channels while restraining velocities and erosion at the largest discharges.

Citation: Jansen, J. D., and G. C. Nanson (2010), Functional relationships between vegetation, channel morphology, and flow efficiency in an alluvial (anabranching) river, J. Geophys. Res., 115, F04030, doi:10.1029/2010JF001657.

\section{Introduction}

[2] Riparian vegetation plays a key role in determining river channel form and dynamics by increasing bank strength and raising flow drag, as shown by a host of recent field, numerical, and physical modeling studies [e.g., Abernethy and Rutherfurd, 2001; Brooks and Brierley, 2002; Eaton and Giles, 2009; Hupp and Osterkamp, 1996; Millar, 2000; Tal and Paola, 2007]. Building on this work we ask how, if riparian vegetation influences channel form, the allied effects of flow drag on channelfloodplain interactions might affect sediment transport in densely vegetated rivers that experience long periods of overbank flow. We study a river that alternates between anabranching and single thread, but our findings relate more

\footnotetext{
${ }^{1}$ School of Geographical and Earth Sciences, University of Glasgow, Glasgow, UK.

${ }^{2}$ Now at Department of Physical Geography and Quaternary Geology, Stockholm University, Stockholm, Sweden.

${ }^{3}$ School of Earth and Environmental Sciences, University of Wollongong, Wollongong, New South Wales, Australia.

Copyright 2010 by the American Geophysical Union. 0148-0227/10/2010JF001657
}

broadly to a wide range of alluvial river patterns wherever vegetation influences bank strength and flow dynamics.

[3] Riparian vegetation is integral to anabranching rivers; those characterized by multiple channels that divide and rejoin around semipermanent vegetated ridges or islands with surface elevations approximating bankfull stage [Harwood and Brown, 1993; Knighton and Nanson, 1993; Tooth and Nanson, 2000]. Such rivers were initially believed to be relatively uncommon. However, a growing number of studies show that in Europe and North America, humans have transformed many anabranching rivers to a single channel so as to maximize floodplain lands for agriculture, transport, and urban development, and such modifications have probably gone unrecorded elsewhere [Brown, 2002; Collins et al., 2002; Herget, 2000; Pišút, 2002]. Moreover, Jansen and Nanson [2004] recognize that the world's five largest rivers anabranch along more than $90 \%$ of their total alluvial tracts and Latrubesse [2008] reports that all alluvial rivers with mean annual discharges $>17,000 \mathrm{~m}^{3} \mathrm{~s}^{-1}$ anabranch. Generalized insights on how rivers function will remain deficient until it is established why many rivers anabranch and have done so in relatively stable configurations for thousands of years.

[4] Anabranching rivers are observed to spill across their islands and floodplains more frequently than the 1-2 year 


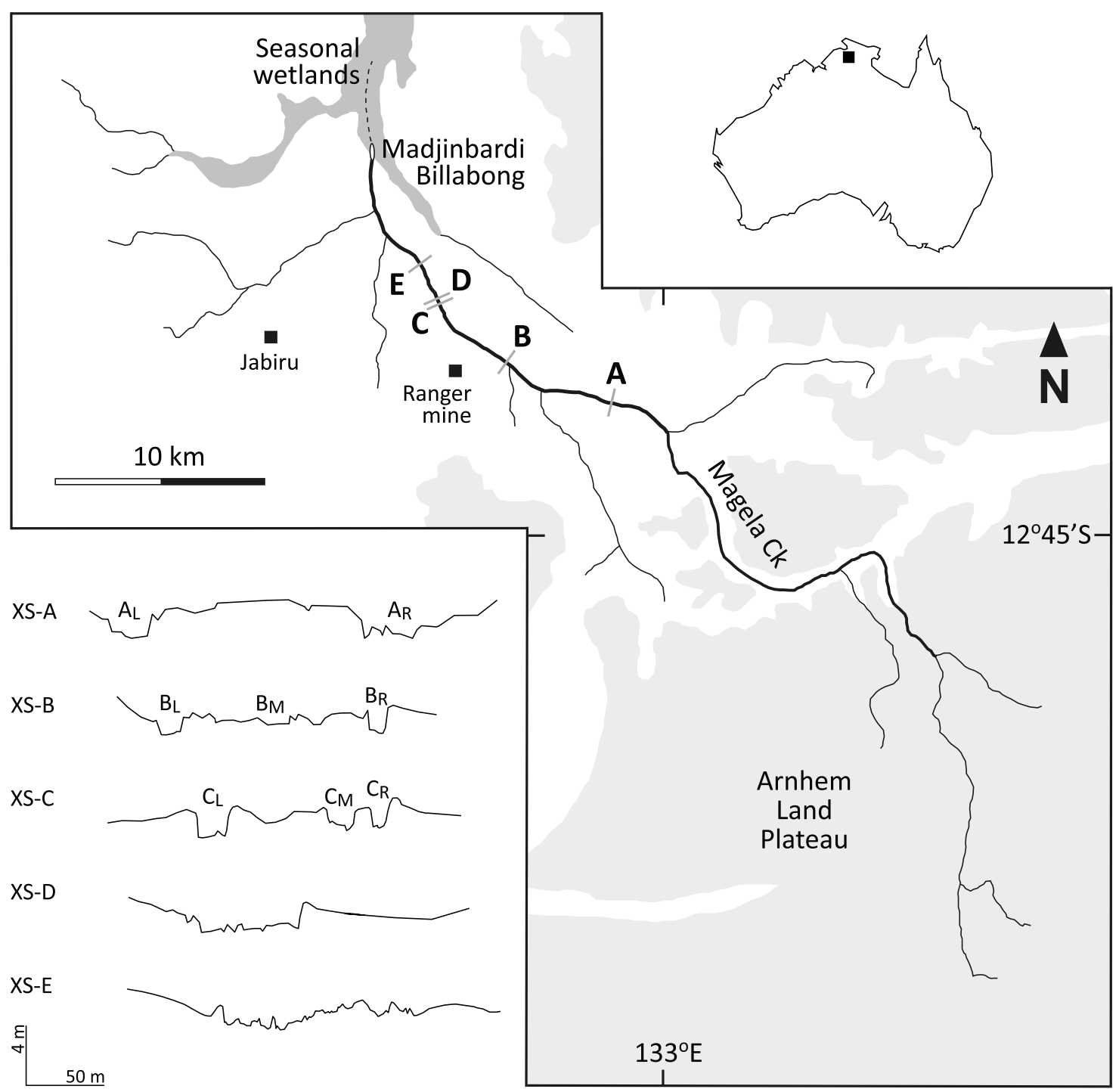

Figure 1. Field area location, including Madjinbardi Billabong and the five study cross sections (XS) spread along a $13 \mathrm{~km}$ long reach at locations A, B, C, D, and E. Note that XS-D and XS-E effectively function as a single channel during flows near or at bankfull. Reach-scale bed slope declines downstream from $\sim 0.0011$ to $\sim 0.0005$, and channel belt sinuosity is $\sim 1.1$. Lower left inset shows individual cross sections and channels within the cross sections. For multichannel cross sections, left, middle, and right channels are denoted by subscript $\mathrm{L}, \mathrm{M}$, and $\mathrm{R}$, respectively.

interval widely reported for single-thread rivers [Jansen and Nanson, 2004; Makaske, 2001; Makaske et al., 2002; Nanson and Knighton, 1996]. As well as being the principal sediment storages, floodplains and islands dissipate a great deal of erosional energy once flows spread overbank. The higher frequency of overbank flooding is suggested to signify a distinctive relationship between anabranching rivers and their floodplains, perhaps linked to their origin and maintenance [Jansen and Nanson, 2004; Nanson and Knighton, 1996]. The hydraulic geometry of anabranching rivers remained unstudied until Tabata and Hickin's [2003] detailed investigation of a $10 \mathrm{~km}$ reach of the upper Columbia River, yet the few data available for anabranching rivers hint at formative processes not examined by overbed hydraulic geometry [Jansen and Nanson, 2004; Knighton and Nanson, 2002]. Moreover, when it comes to the transport of sediment at discharges exceeding bankfull, our poor understanding of all alluvial river patterns reflects the lack of empirical data [Ackers, 1992].

[5] In this paper, riparian vegetation and overbank flooding are shown to be integral to the maintenance of many alluvial (anabranching) rivers, and especially those formed in uncohesive sediments. Utilizing data that extend to both overbed and overbank zones, flow properties, sediment transport and hydraulic geometry were analyzed in Magela Creek, a sand bed river in the seasonal wet-dry tropics of northern Australia (Figure 1). Contrasting water and sediment flux interactions are examined for single-thread and anabranching channel reaches (and their floodplains) using flow data allied with field-measured and mathematically modeled bed load transport data for 10 independent channels (at five stations). The five stations span the $\sim 12 \mathrm{~km}$ 
Table 1. Summary Attributes of the Five Study Stations Along Magela Creek, Including Three Official Stream Gauge Stations (GS) and Two Sites at Which Bed Load Transport Has Been Measured in the Field

\begin{tabular}{lcccccc}
\hline \multicolumn{1}{c}{ Site } & Channels & Distance $^{\mathrm{a}}(\mathrm{km})$ & Flow Record & $\begin{array}{c}\text { Flow Ratings } \\
(\text { Total })\end{array}$ & $\begin{array}{c}\text { Max. Rated } \\
\text { Flow }^{3} \mathrm{~m}^{-1} \text { ) }\end{array}$ & $\begin{array}{c}\text { Recurrence of Maximum } \\
\text { Rated Flow }(\text { years })\end{array}$ \\
\hline XS-A, GS-8210028 $^{\mathrm{b}}$ & 2 & 17.0 & $1979-1993$ & $28(97)$ & 220 & $\sim 1.5$ \\
XS-B, GS-8210067 $^{\mathrm{c}}$ & 3 & 11.0 & $1983-2001$ & $29(>58)$ & 646 & $\sim 3.5$ \\
XS-C $^{\mathrm{d}}$ & 3 & 5.9 & $1986-1989$ & $22(22)$ & 340 & $\sim 1.8$ \\
XS-D, GS-8210009 $^{\text {b,e }}$ & 1 & 5.5 & $1972-2001$ & $33(176)$ & 540 & $\sim 2.5$ \\
XS-E $^{\mathrm{f}}$ & 1 & 3.5 & 2002 & $10(10)$ & 150 & $\sim 1.1$ \\
\hline
\end{tabular}

${ }^{\mathrm{a}}$ Measured upstream of Madjinbardi Billabong.

${ }^{b}$ Northern Territory Department of Land, Planning and Environment (unpublished data, 1979-1993).

${ }^{c}$ Also known as Release Point, Energy Resources Australia, Ranger Mine (unpublished data, 1979-1993).

dMeasurements by Roberts [1991]; known as "anabranches" in the study by Jansen and Nanson [2004].

"Known as "single channel A" in the study by Jansen and Nanson [2004]. The drainage area at XS-D is $\sim 600 \mathrm{~km}^{2}$.

"Known as "single channel B" in the study by Jansen and Nanson [2004].

reach and consist of two single channel, one double anabranch, and two triple-anabranch sites. At-station and downstream (interchannel) hydraulic geometry are described for more than 200 flow ratings extending up to 6.2 times bankfull flow depth. Effective discharge and mass flux balance are calculated through the $\sim 12 \mathrm{~km}$ reach to determine flow efficiency (i.e., bed load transport per unit stream power) of each of the channels at each station. Hydraulic geometry and bed load transport are strongly influenced by riparian vegetation. During high flows, dense bank vegetation impedes mixing between overbed and overbank floodwaters, confining high velocity flow to the zone over the channel bed, such that rather than declining, bed load transport rate is maximized at more than twice bankfull flow. The interplay between biogeomorphic factors is assessed in the context of a wider understanding of the controls on single-thread versus anabranching river patterns.

\section{Definitions: Effective Discharge, Dominant Discharge, and Bankfull Discharge}

[6] A key aim of discharge magnitude-frequency analysis is to evaluate the effectiveness, usually in terms of sediment transport, of a given flow magnitude in shaping alluvial channels and their floodplains [Wolman and Miller, 1960]. The effective sediment-transporting discharge $\left(Q_{e}\right)$ is the discharge interval that is most effective in the long term transport of sediment under steady state conditions [Andrews, 1980; Emmett and Wolman, 2001; Pickup and Warner, 1976]. Dominant discharge $\left(Q_{d}\right)$ refers to the discharge that determines the characteristics and principal dimensions of the channel, and is also known as the formative or channel-forming discharge [Bates and Jackson, 1987, p.199].

[7] Wolman and Miller [1960] state that the most significant discharge influencing alluvial channel capacity is that which transports most bed material for its given frequency of recurrence (i.e., $Q_{d} \approx Q_{e}$ ), which they equate with bankfull discharge $\left(Q_{b}\right)$. There has been a great deal of data collected and debate generated to determine the validity, equivalence, and recurrence intervals of all three quantities [e.g., Andrews, 1980; Emmett and Wolman, 2001; Nash, 1994; Richards, 1999], but rather than advance this discussion in relation to alluvial rivers in general, the aim here is to present evidence that pertains specifically to the recurrence interval and role of some identifiably influential discharge in causing and maintaining the anabranching nature of Magela Creek.

[8] Discharges $Q_{e}$ and $Q_{d}$ in anabranching rivers are poorly understood. In their analysis of the anabranching Columbia River, Tabata and Hickin [2003] assume that $Q_{d} \approx Q_{e} \approx Q_{b}$. Jansen and Nanson [2004] report for Magela Creek that: 1., $Q_{e}$ exceeds $Q_{b}$ in anabranching reaches, thus overbed-overbank flow interactions are integral to channel-forming processes; 2., anabranching channels optimize flow efficiency, that is, they maximize bed load sediment transport $\left(Q_{s}\right)$ per unit stream power $(\Omega)$ compared with interspersed single-channel reaches; and 3., sediment flux balance prevails over time frames of $1-10^{2}$ years, and possibly longer. Note that we use the term "bed load" as shorthand for "bed material load" being inclusive of suspended sand-sized particles $(>63 \mu \mathrm{m})$.

\section{Field Area}

[9] Anabranching in Magela Creek is developed below the Arnhem Land plateau (Figure 1), a 250-300 m upland cut in resistant Palaeoproterozoic Kombolgie sandstone [Needham, 1988]. Sand bed anabranches carry seasonal floods $\sim 24 \mathrm{~km}$ to Madjinbardi Billabong, which marks the end of the bed load-dominated reach and the beginning of seasonal wetlands where the channel breaks lengthwise into a series of discrete billabongs (waterholes) before entering the tidal East Alligator River. The anabranching reach comprises up to five independent channels that rarely converge into a single channel (such occurs at four places in the alluvial section and in each case flow splits again within $150 \mathrm{~m}$ ). Each anabranch is typically close to straight with comparatively simple trapezoidal cross sections divided by narrow, vegetated alluvial ridges up to $2 \mathrm{~m}$ high and tens of meters long, or broader islands up to $100 \mathrm{~m}$ wide and $1000 \mathrm{~m}$ long, similar to other well-vegetated sand load anabranching rivers described from Australia [e.g., Nanson and Knighton, 1996; Tooth and Nanson, 2000, 2004; Wende and Nanson, 1998]. Five stations (A-E; cross sections indicated by XS), with representative configurations of one to three channels spread along a $\sim 12 \mathrm{~km}$ reach, were selected for detailed comparison of flow, bed load transport, and channel and floodplain characteristics (Figure 1). Three of the stations (XS-A, XS-B, and XS-D) correspond to flow gauge stations managed by a state 

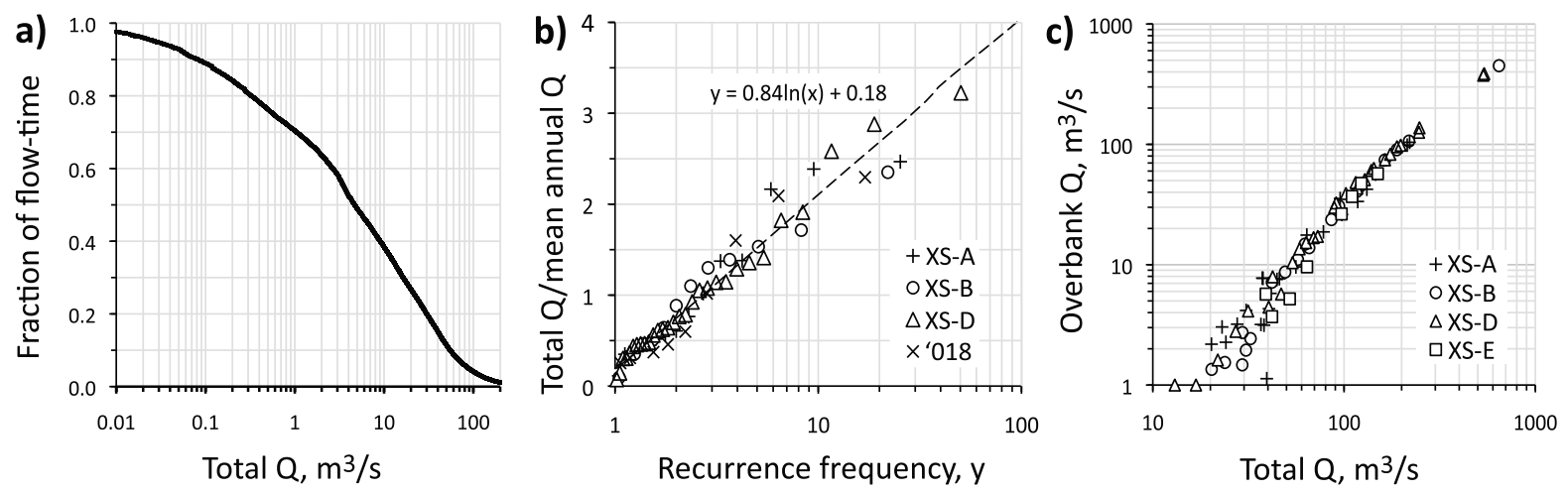

Figure 2. (a) Flow duration curve at XS-D (1972-2001). Note that $Q>0$ for $53 \%$ of the year, on average. (b) Annual maximum flood series and least squares regression for data combined from four flow gauges on Magela Creek (including GS-8210018 at Madjinbardi Billabong indicated by '018). Total discharge is normalized by mean annual flood in order to compare discharge between gauges (see Table 1 for flow gauge attributes). For XS-D (the longest flow record), mean discharge (excluding no-flow periods) is $21.1 \mathrm{~m}^{3} \mathrm{~s}^{-1}$; mean annual flood is $525 \mathrm{~m}^{3} \mathrm{~s}^{-1}$; the 5 year and 10 year floods are $840 \mathrm{~m}^{3} \mathrm{~s}^{-1}$ and $1180 \mathrm{~m}^{3} \mathrm{~s}^{-1}$, respectively; and the flood of record (February 1980) is $1700 \mathrm{~m}^{3} \mathrm{~s}^{-1}$. Bankfull capacity (for all anabranches combined) at each of the five study stations $\left(15-26 \mathrm{~m}^{3} \mathrm{~s}^{-1}\right)$ has a recurrence frequency of $\sim 1.01 \mathrm{yr}$. (c) Overbank discharge versus total discharge, showing the growth of overbank discharge (i.e., flow conveyed over islands or floodplains) at each of the five stations (note that this data is not available for XS-C).

agency and two (XS-C and XS-E) were established for this study (Table 1).

\subsection{Sediment Flux and Hydrology}

[10] Previous studies have established a sound understanding of long-term sediment flux and Quaternary evolution based on more than 140 radiocarbon, luminescence, and uranium-series dates spanning the past $300 \mathrm{kyr}$ [Nanson et al., 1993; Nott and Roberts, 1996; Roberts, 1991; Tooth et al., 2008; Wasson, 1992]. The modern creek flows atop a $110-190 \mathrm{~m}$ wide inset trench filled with $8-12 \mathrm{~m}$ of Holocene coarse to medium sands. The Holocene trench has vertically aggraded $1-2 \mathrm{~mm} \mathrm{yr}^{-1}$ over the past 3000 years, but now appears to be close to its maximum capacity as defined by the level of adjacent Pleistocene alluvium which further accretion would onlap [Nanson et al., 1993]. Optically stimulated luminescence ages from islands between the anabranches show that riparian vegetation facilitates island growth and an associated temporal shift from wide shallow braided channels to deeper more transport efficient anabranching channels over the past 2000-3000 years [Tooth et al., 2008].

[11] Magela Creek's sediment load of predominantly unimodal medium sands $\left(D_{50}=0.42 \mathrm{~mm}, D_{90}=0.72 \mathrm{~mm}\right)$ derives mainly from the quartzose Kombolgie sandstone in the headwaters. The channel bed hosts dune bed forms approximately $0.3 \mathrm{~m}$ high, often with superposed ripples, and low concentrations of suspended sediment, $12-15 \mathrm{mg} \mathrm{L}^{-1}$, are typical due to high water temperatures $\left(26^{\circ} \mathrm{C}-34^{\circ} \mathrm{C}\right)$ and therefore low kinematic viscosity [Hart et al., 1987; Roberts, 1991]. For the period 1971-1989, Roberts [1991] estimates the terrigenous sediment yield transported past XS-D at $12,051 \mathrm{t} \mathrm{yr}^{-1}$, consisting of $43 \%$ bed load, $45 \%$ wash load, and $12 \%$ solutes. These estimates of bed load yield are corroborated by measurements of the rate of delta progradation into Madjinbardi Billabong, the present locus of sand storage in the Magela system. Aerial photographs and detailed field surveys in 1980, 1989, and 2002 [Jansen and Nanson, 2003; Roberts, 1991] indicate that sand accumulation at the delta has remained steady at $\sim 900 \pm 80 \mathrm{~m}^{3} \mathrm{yr}^{-1}$ [Jansen and Nanson, 2003]. Unlike the creek at Madjinbardi, the study reach is predominantly a sediment transfer zone; the channels are laterally stable and the anabranching pattern is well defined [cf. Jansen and Nanson, 2004; Tooth et al., 2008].

[12] Seasonal alternation of flood and drought is the dominant feature of the field area's wet-dry tropical climate; the flow duration curve and annual flood series are given in Figures $2 \mathrm{a}$ and $2 \mathrm{~b}$. About $83 \%$ of the mean annual rainfall of $1545 \mathrm{~mm}$ occurs within the December-March wet season (Jabiru airport, unpublished data, 1971-2009), and pan evaporation is $2580 \mathrm{~mm}(1973-1990)$. The first flows in Magela Creek arrive in November-December and by the end of March over $80 \%$ of the total annual flow has passed. Little or no flow $\left(<0.1 \mathrm{~m}^{3} \mathrm{~s}^{-1}\right)$ occurs for half the year, yet Magela Creek also spends long periods spread over its islands and floodplains; the duration of overbank flow varies from 12 to 93 days per year at the 10 channels studied.

\subsection{Riparian Vegetation and Sedimentation Patterns}

[13] The lowlands and floodplains support a mixture of tall open forests, woodland savannah, and grassland [Story, 1976]. Melaleuca argentea, M. leucadendra, and Syzygium forte form linear groves on the ridges, whereas Lophopetalum arnhemicum characterizes broader islands [Erskine, 2002]. Ridges and islands are stabilized by thick vegetation with banks reinforced by dense root mats beneath mature Lophopetalum arhemicum and Melaleuca spp., the largest of which are probably more than a century old [cf. Fielding et al., 1997]. M. argentea and M. leucadendra are capable of surviving once established directly on the channel bed over 
Table 2. Summary Vegetation and Substrate Characteristics of the Bank Erodibility Test Sites [Erskine, 2002]

\begin{tabular}{|c|c|c|c|c|}
\hline Sites & Main Tree Species Present in Order of Frequency & $\begin{array}{l}\text { Tree Density } \\
\left(\text { trees }\left(100 \mathrm{~m}^{-2}\right)\right)\end{array}$ & $\begin{array}{l}\text { Tree Basal Area } \\
\left.\mathrm{m}^{2}\left(100 \mathrm{~m}^{-2}\right)\right)\end{array}$ & $\begin{array}{l}\text { Grain Size }{ }^{\mathrm{b}} \\
(\% \text { sand })\end{array}$ \\
\hline $\mathrm{XS}-\mathrm{C}$ & $\begin{array}{c}\text { Lophopetalum arnhemicum, Corymbia porrecta, } \\
\text { Syzygium forte, Carallia brachiata, } \\
\text { Barringtonia acutangula, Pandanus aquaticus. }\end{array}$ & 10.3 & 1.998 & 93 \\
\hline XS-E & $\begin{array}{l}\text { Melaleuca argentea, M. viridiflora, } \text { M. leucadendra, } \\
\text { Barringtonia acutangula, Pandanus aquaticus. }\end{array}$ & 2.8 & 0.193 & 85 \\
\hline
\end{tabular}

\footnotetext{
${ }^{\mathrm{a}}$ Tree surveys were conducted using the point-centered quarter method.

${ }^{\mathrm{b}}$ Forty-five sediment samples were analyzed.
}

the dry season, making them key species for stabilizing channel sediment [Fielding et al., 1997]; Melaleuca spp. and Syzygium forte are similarly important trees on the ridges, with Barringtonia acutangula and Pandanus aquaticus being common midstorey shrubs. These latter shrubs are also observed occasionally colonizing the channel bed, suggesting a possible stabilizing and nutrient-fixing role for successional species. The stability of the main anabranching channels is reflected in the colonnade-like rows of Lophopetalum arnhemicum that reinforce the banks and form a partial canopy over the clumps of vine-forest draping the islands [Erskine, 2002]. Despite the uncohesive, sandy channel boundary, the reinforcing effect of vegetation ensures that Magela anabranches are stable and long-lived [Erskine, 2002; Tooth et al., 2008]. The larger islands accrete vertically with sandy levees sloping down to a slightly muddier top stratum in the interior flood basin, though not all islands have such a basin. The heads of islands appear draped in fresh sand splays; however, aerial photography from 1950 reveals that despite numerous overbank flows per year, minimal planform change has occurred [Roberts, 1991]. Lateral channel stability is consistent with the scarcity of point bars or eroding banks. Occasional crevasse splays are observed on the floodplain, and there is a general lack of evidence for channel avulsion.

\subsection{Bank Erodibility Tests}

[14] Erskine [2002] investigates the influence of riparian vegetation on bank erodibility at two contrasting sites along Magela Creek: Sites XS-C, with its narrow and deep anabranching channels, and XS-E, a relatively wide and shallow single channel (Figure 1). Having used the "pointcentered quarter method" of tree sampling, and measured the breast height cross-sectional area for each sampled tree, the absolute basal areas $\left(\mathrm{cm}^{2}\left(100 \mathrm{~m}^{2}\right)^{-1}\right)$ were determined for the banks at each of the two sites (Table 2). XS-C hosts a dense monsoonal community with bank-reinforcing root systems that in the case of the dominant species Lophopetalum arnhemicum, effectively buttress the banks. At XS-C the density of tree cover is nearly four times greater than at XS-E, and absolute basal area is more than 10 times greater than at XS-E (Table 2), which consists of scattered woodland savannah and an understory of grass. Dense root mats were observed on the banks at both sites, especially beneath Lophopetalum arnhemicum, Syzigium forte, and Melaleuca spp.

[15] The banks comprise relatively homogeneous to slightly stratified sand (Table 2), and hydraulic action appears to be the main erosional mechanism. Potential bank erodibility was tested with a device that directs a stream of water onto a bank at $200 \mathrm{KPa}$ for $30 \mathrm{~s}$ from a pressurized backpack; the eroded sediment being collected in a trough below. From 15 repeated tests, the average erosion rate was $7.6 \pm 4.5 \mathrm{~g} \mathrm{~s}^{-1}$ for grass-covered banks; $4.8 \pm 2.6 \mathrm{~g} \mathrm{~s}^{-1}$ for tree lined banks; and $1.4 \pm 0.76 \mathrm{~g} \mathrm{~s}^{-1}$ for root mats. While the one-sigma uncertainty shows that variability within each bank type is considerable, the results suggest that the grassdominated XS-E single-channel banks are more erodible than the heavily treed banks lining the XS-C anabranches, and areas of root mat are the least erodible of all (at both XS). The combination of trees and their root mats along the XS-C anabranches fosters banks that are substantially more resistant to erosion than the less-densely vegetated banks at XS-E, and we return to this point below.

\section{Hydraulic Geometry: Approach and Methods}

[16] At-station hydraulic geometry illustrates how flow geometry adjusts with increasing discharge through a cross section [Leopold and Maddock, 1953]. Whereas most data sets end at or close to bankfull, data were obtained in Magela Creek at flow depths up to 6.2 times bankfull depth and at discharges up to 15 times bankfull capacity. A particular aim is to identify discontinuities in velocity and allied variables associated with lateral interactions between overbed and overbank portions (defined below) of the total discharge. Such interactions have important implications for boundary shear, bed load transport, and therefore channel morphology. Knight and Demetriou [1983] suggest relative depth $(R D)$ as a measure of this interaction, as given by

$$
R D=\left(d-d_{b}\right) / d
$$

where $d$ is mean flow depth, $d_{b}$ is bankfull mean flow depth, and $\left(d-d_{b}\right)$ is floodplain depth. Negative values indicate subbankfull whereas positive values indicate the relative depths of overbank flow. Knight and Shiono [1996] find that retardation of overbed flow coupled with quickening flow over the floodplain is typically maximized at $R D \sim 0.1-0.3$; an argument supported with field data from the anabranching Cooper Creek [Knighton and Nanson, 2002]. RD characteristics are obtained for the 10 individual channels in Magela Creek.

[17] Total discharge $\left(Q_{t}\right)$ is split among the channels and the overbank zone, but bed load is transported entirely overbed, and hence overbed conditions are of chief importance for understanding how channel morphology and flow dynamics govern bed load transport. Overbed flow $\left(Q_{c}\right)$ is defined as the discharge conveyed above the channel bed 
A) XS-A

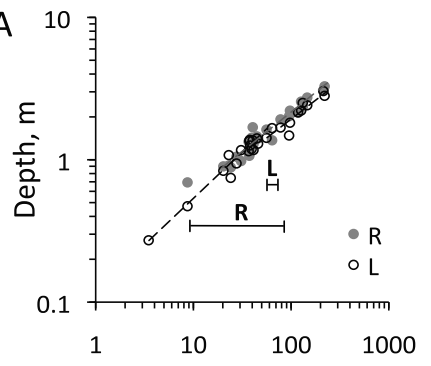

B) XS-B

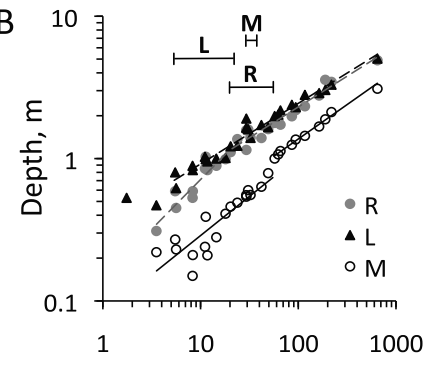

C) XS-C

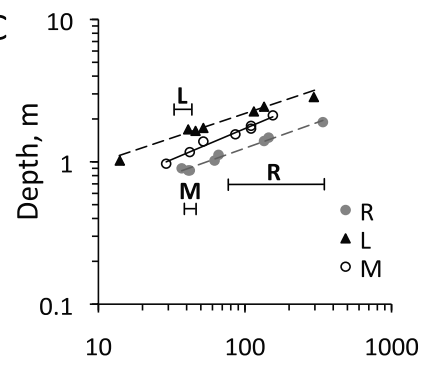

D) XS-D 10

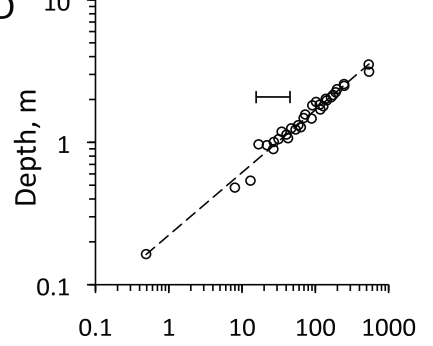

E) XS-E 10 录

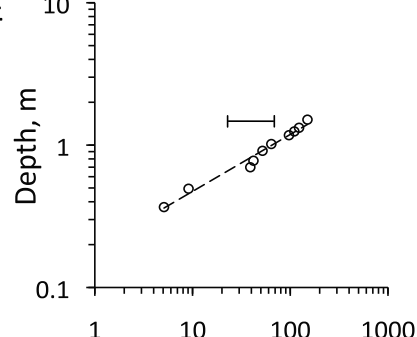

F)

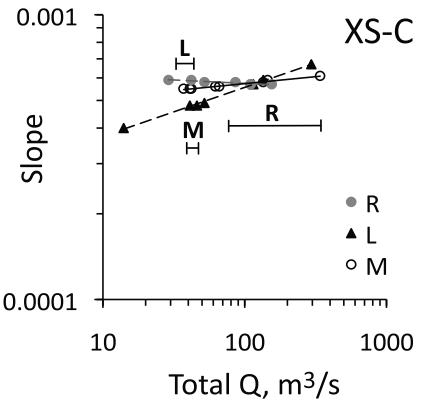

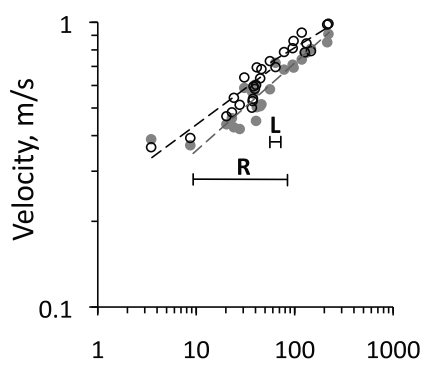
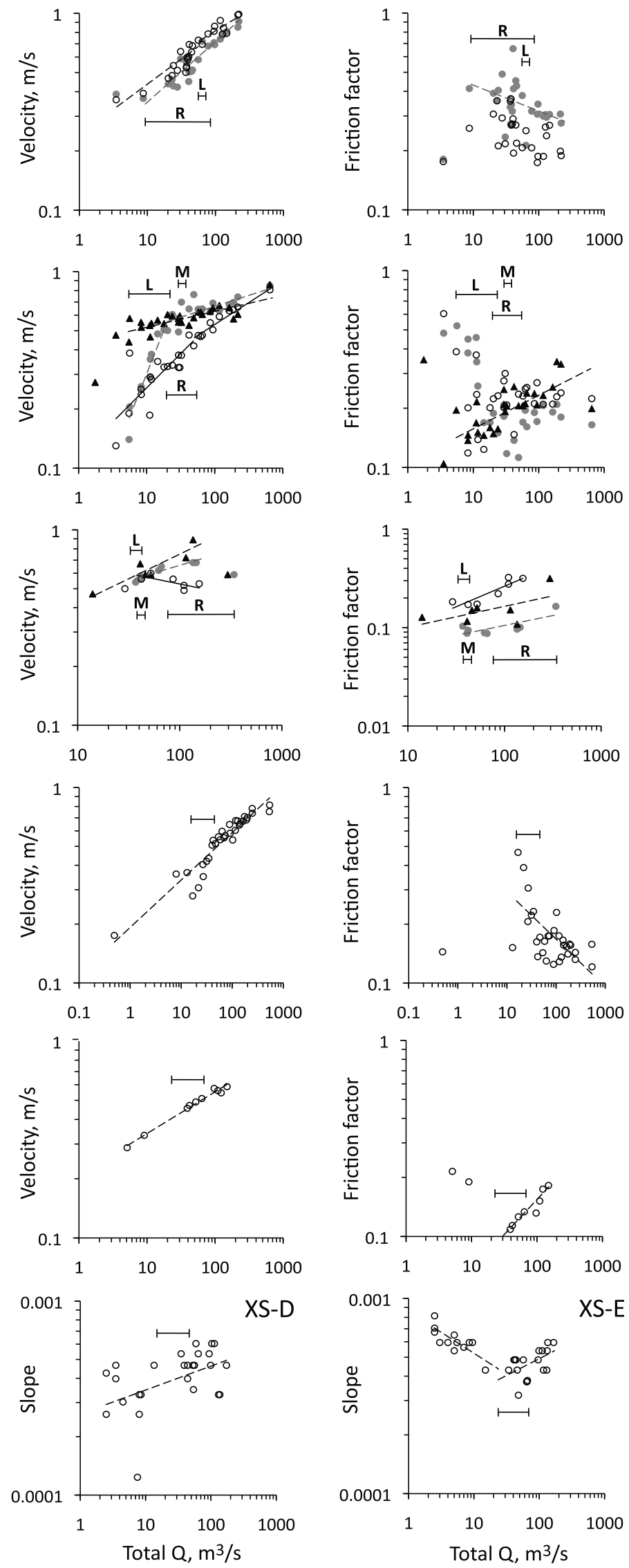

Figure 3 
Table 3. At-Station Hydraulic Geometry Relationships ${ }^{\mathrm{a}}$

\begin{tabular}{|c|c|c|c|c|c|c|c|c|c|c|c|c|}
\hline \multirow[b]{2}{*}{ Q Range } & \multicolumn{3}{|c|}{ Depth $d=c Q^{f}$} & \multicolumn{3}{|c|}{ Velocity $v=k Q^{m}$} & \multicolumn{3}{|c|}{ Friction Factor $\mathrm{ff}=h Q^{p}$} & \multicolumn{3}{|c|}{ Slope $s=t Q^{z}$} \\
\hline & $c$ & $f$ & $\rho 95 \% \mathrm{CI}^{\mathrm{b}}$ & $k$ & $m$ & $\rho 95 \% \mathrm{CI}^{\mathrm{b}}$ & $h$ & $p$ & $\rho 95 \% \mathrm{Cl}^{\mathrm{b}}$ & $t$ & $z$ & $\rho 95 \% \mathrm{CI}^{\mathrm{b}}$ \\
\hline $\begin{array}{l}Q>Q_{b} \\
Q<Q_{b}\end{array}$ & $\begin{array}{l}0.15 \\
0.13\end{array}$ & $\begin{array}{l}0.55 \\
0.63\end{array}$ & $\begin{array}{l}0.67 \text { to } 0.98 \\
0.93 \text { to } 0.99\end{array}$ & $\begin{array}{l}0.29 \\
0.24\end{array}$ & $\begin{array}{l}0.23 \\
0.24\end{array}$ & $\begin{array}{l}\quad X S-A_{L} \\
0.39 \text { to } 0.96 \\
0.68 \text { to } 0.95\end{array}$ & & & $\begin{array}{l}\text { NS } \\
\text { NS }\end{array}$ & & & \\
\hline $\begin{array}{l}Q>Q_{b} \\
Q<Q_{b}\end{array}$ & 0.17 & 0.55 & $\begin{array}{r}0.94 \text { to } 0.99 \\
\text { NS }\end{array}$ & 0.18 & 0.30 & $\begin{array}{r}X S-A_{R} \\
0.84 \text { to } 0.97 \\
\text { NS }\end{array}$ & 0.57 & -0.13 & $\begin{array}{r}-0.67 \text { to } 0.03 \\
\mathrm{NS}\end{array}$ & & & \\
\hline $\begin{array}{l}Q>Q_{b} \\
Q<Q_{b}\end{array}$ & 0.35 & 0.42 & $\begin{array}{r}0.97 \text { to } 0.99 \\
\text { NS }\end{array}$ & 0.44 & 0.08 & $\begin{array}{r}X S-B_{L} \\
0.58 \text { to } 0.90 \\
\text { NS }\end{array}$ & 0.11 & 0.17 & $\begin{array}{r}0.46 \text { to } 0.86 \\
\text { NS }\end{array}$ & & & \\
\hline $\begin{array}{l}Q>2 Q_{b} \\
Q<2 Q_{b}\end{array}$ & $\begin{array}{l}0.16 \\
0.08\end{array}$ & $\begin{array}{l}0.47 \\
0.56\end{array}$ & $\begin{array}{r}0.97 \text { to } 1.0 \\
0.71 \text { to } 0.96\end{array}$ & $\begin{array}{l}0.18 \\
0.12\end{array}$ & $\begin{array}{l}0.24 \\
0.33\end{array}$ & $\begin{array}{l}\quad X S-B M \\
0.90 \text { to } 0.99 \\
0.48 \text { to } 0.91\end{array}$ & & & $\begin{array}{l}\text { NS } \\
\text { NS }\end{array}$ & & & \\
\hline $\begin{array}{l}Q>Q_{b} \\
Q<Q_{b}\end{array}$ & $\begin{array}{l}0.31 \\
0.14\end{array}$ & $\begin{array}{l}0.43 \\
0.72\end{array}$ & $\begin{array}{l}0.92 \text { to } 0.99 \\
0.71 \text { to } 0.98\end{array}$ & $\begin{array}{l}0.40 \\
0.05\end{array}$ & $\begin{array}{l}0.11 \\
0.78\end{array}$ & $\begin{array}{l}\quad X S-B_{R} \\
0.44 \text { to } 0.90 \\
0.69 \text { to } 0.98\end{array}$ & & & $\begin{array}{l}\text { NS } \\
\text { NS }\end{array}$ & & & \\
\hline $\begin{array}{l}\text { All } Q \\
Q>Q_{b} \\
Q<5 Q_{b} \\
Q<Q_{b}\end{array}$ & $\begin{array}{l}0.45 \\
0.56 \\
0.39\end{array}$ & $\begin{array}{l}0.34 \\
0.29 \\
0.37\end{array}$ & $\begin{array}{r}0.91 \text { to } 1.0 \\
0.91 \text { to } 1.0^{\mathrm{c}} \\
0.93 \text { to } 1.0^{\mathrm{c}} \\
\mathrm{NS}\end{array}$ & 0.24 & 0.24 & $\begin{array}{r}X S-C_{L} \\
\text { NS } \\
\text { NS } \\
0.43 \text { to } 0.99 \\
\text { NS }\end{array}$ & 0.06 & 0.21 & $\begin{array}{r}-0.29 \text { to } 0.93 \\
\text { NS } \\
\text { NS }\end{array}$ & $\begin{array}{l}3 \mathrm{E}-4 \\
3 \mathrm{E}-4\end{array}$ & $\begin{array}{l}0.17 \\
0.17\end{array}$ & $\begin{array}{r}0.99 \text { to } 1.0 \\
0.98 \text { to } 1.0^{\mathrm{c}} \\
\mathrm{NS}\end{array}$ \\
\hline $\begin{array}{l}\text { All } Q \\
Q>Q_{b} \\
Q<Q_{b}\end{array}$ & $\begin{array}{l}0.23 \\
0.26\end{array}$ & $\begin{array}{l}0.44 \\
0.41\end{array}$ & $\begin{array}{r}0.92 \text { to } 1.0 \\
0.83 \text { to } 1.0^{\mathrm{c}} \\
\mathrm{NS}\end{array}$ & 0.84 & -0.10 & $\begin{array}{r}X S-C_{M} \\
\text { NS } \\
-0.96 \text { to } 0.26 \\
\text { NS }\end{array}$ & $\begin{array}{l}0.04 \\
0.02\end{array}$ & $\begin{array}{l}0.42 \\
0.55\end{array}$ & $\begin{array}{r}0.46 \text { to } 0.99 \\
0.60 \text { to } 0.99^{\mathrm{c}} \\
\mathrm{NS}\end{array}$ & $\begin{array}{l}6 \mathrm{E}-4 \\
6 \mathrm{E}-4\end{array}$ & $\begin{array}{l}-0.02 \\
-0.03\end{array}$ & $\begin{array}{r}-0.99 \text { to }-0.62 \\
-0.99 \text { to }-0.38^{\mathrm{c}} \\
\mathrm{NS}\end{array}$ \\
\hline $\begin{array}{l}\text { All } Q \\
Q>Q_{b} \\
Q<2 Q_{b} \\
Q<Q_{b}\end{array}$ & $\begin{array}{l}0.23 \\
0.20\end{array}$ & $\begin{array}{l}0.37 \\
0.40\end{array}$ & $\begin{array}{r}0.96 \text { to } 1.0 \\
\mathrm{NS} \\
0.28 \text { to } 1.0^{\mathrm{c}}\end{array}$ & 0.32 & 0.16 & $\begin{array}{r}X S-C_{R} \\
\text { NS } \\
\text { NS } \\
0.63 \text { to } 0.99 \\
\text { NS }\end{array}$ & 0.04 & 0.20 & $\begin{array}{r}0.11 \text { to } 0.95 \\
\text { NS }\end{array}$ & $5 \mathrm{E}-4$ & 0.05 & $\begin{array}{r}0.96 \text { to } 1.0 \\
\mathrm{NS} \\
\mathrm{NS}\end{array}$ \\
\hline $\begin{array}{l}\text { All } Q \\
Q>Q_{b} \\
Q<Q_{b}\end{array}$ & $\begin{array}{l}0.22 \\
0.26\end{array}$ & $\begin{array}{l}0.44 \\
0.41\end{array}$ & $\begin{array}{r}0.98 \text { to } 0.99 \\
0.97 \text { to } 0.99^{\mathrm{c}} \\
\mathrm{NS}\end{array}$ & $\begin{array}{l}0.19 \\
0.16\end{array}$ & $\begin{array}{l}0.24 \\
0.28\end{array}$ & $\begin{array}{r}X S-D \\
0.90 \text { to } 0.97 \\
0.83 \text { to } 0.96^{\mathrm{c}} \\
\text { NS }\end{array}$ & 0.51 & -0.24 & $\begin{array}{r}-0.83 \text { to }-0.41 \\
\mathrm{NS}\end{array}$ & $3 \mathrm{E}-4$ & 0.12 & $\begin{array}{r}0.13 \text { to } 0.72 \\
\text { NS } \\
\text { NS }\end{array}$ \\
\hline $\begin{array}{l}\text { All } Q \\
Q>Q_{b} \\
Q<Q_{b}\end{array}$ & $\begin{array}{l}0.19 \\
0.11\end{array}$ & $\begin{array}{l}0.40 \\
0.52\end{array}$ & $\begin{array}{r}0.95 \text { to } 1.0 \\
0.94 \text { to } 1.0^{\text {c }} \\
\text { NS }\end{array}$ & $\begin{array}{l}0.21 \\
0.24\end{array}$ & $\begin{array}{l}0.21 \\
0.18\end{array}$ & $\begin{array}{r}X S-E \\
0.97 \text { to } 1.0 \\
0.79 \text { to } 0.99^{\mathrm{c}} \\
\mathrm{NS}\end{array}$ & 0.03 & 0.34 & $\begin{array}{r}\mathrm{NS} \\
0.71 \text { to } 0.99 \\
\mathrm{NS}\end{array}$ & $\begin{array}{l}2 \mathrm{E}-4 \\
8 \mathrm{E}-4\end{array}$ & $\begin{array}{r}0.17 \\
-0.21\end{array}$ & $\begin{array}{r}0.05 \text { to } 0.79 \\
-0.94 \text { to }-0.41\end{array}$ \\
\hline
\end{tabular}

${ }^{\mathrm{a}}$ For multichannel sites, left, middle, and right channels are denoted by subscript $\mathrm{L}, \mathrm{M}$ and $\mathrm{R}$, respectively. Least squares regressions are applied to subsets of the data indicated by the $Q$ range column on the left (where $Q_{b} \sim$ minimum $w / d$, see Table 4 ), and these are plotted in Figure 3. Correlations that are not statistically significant are denoted by NS, and shading indicates no data available.

${ }^{\mathrm{b}}$ The $95 \%$ confidence limits of the correlation coefficient.

${ }^{\mathrm{c}}$ Regression lines of best fit not shown in Figure 3.

delineated by projecting vertical "fences" and setting velocity to zero at the left and right edge of the mobile sand bed. All discharge measurements are calculated using the mean section method [Gregory and Walling, 1973, p.132], and all flow data presented here (width, depth, and velocity) are consistent with widely followed recommendations for measuring open channel flow [i.e., Edwards and Glysson,
1998; Emmett, 1980]. Flow velocity was measured with a rod-mounted Ott C31 impeller-type current meter and mean velocity at each station was taken as the average of four measurements over $40 \mathrm{~s}$ intervals at $0.2,0.4,0.6$, and 0.8 of flow depth. Water surface slopes were measured using temporary stage boards for 18 separate floods at XS-C, XS$\mathrm{D}$, and XS-E, spanning a total stream length at each site of

Figure 3. At-station hydraulic geometry scatterplots at the five stations (10 channels). $Q_{b}$ is indicated for each channel as a range of discharges defined by the high bank and the low bank (the left side of the $Q_{b}$ bracket indicates minimum $w / d$ geometry). All regression lines shown are statistically significant at the $95 \%$ level. Separate regressions are applied to subsets of the data where segmentation occurs, and all parameters are listed in Table 3. (a-e) Mean depth, mean overbed velocity, and friction factor versus total discharge for each cross section. (f) Water slope versus total discharge for three stations: XS-C, XS-D, and XS-E. 

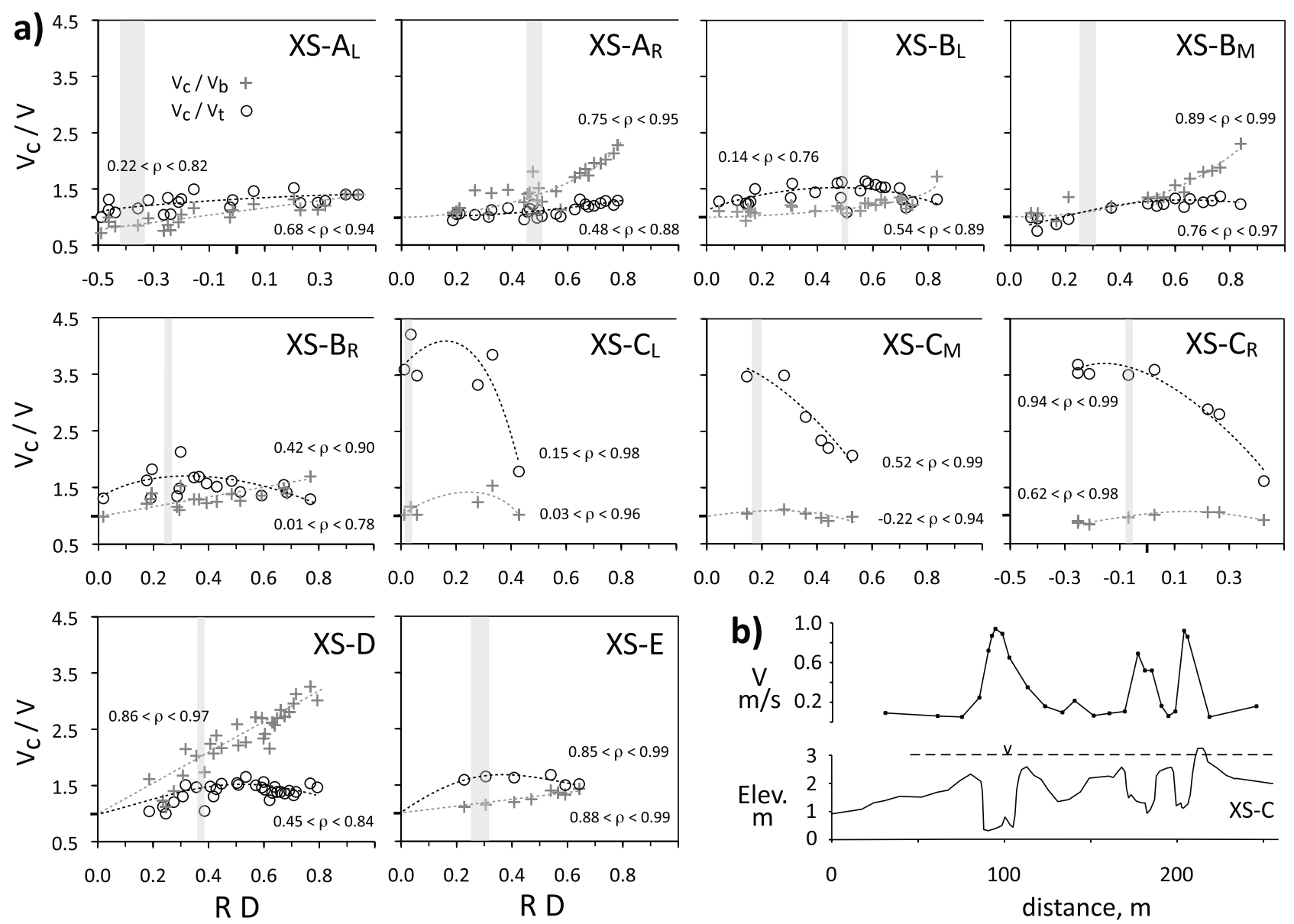

Figure 4. (a) $V_{c} / V_{b}$ versus relative flow depth $R D$ (see equation (1)), where $V_{c}$ is mean overbed velocity, $V_{b}$ is mean overbed velocity at bankfull; and $V_{c} / V_{t}$, where $V_{t}$ is mean velocity for the full valley section. Quadratic curves (with 95\% confidence limits of the correlation coefficient) are fitted with the aim of smoothing the data and guiding the eye. Note that the effective discharge $\left(Q_{e}=40-45 \mathrm{~m}^{3} \mathrm{~s}^{-1}\right)$ is indicated by shaded vertical bands, and for XS- $\mathrm{A}_{\mathrm{L}}$ and $\mathrm{XS}-\mathrm{C}_{\mathrm{R}}$ the RD axes extend to negative values because for these channels $Q_{e}<Q_{b}$. (b) Mean flow velocity and water surface transect measured at the XS-C anabranches on $23 \mathrm{Feb} 2002$ when $Q_{t}=107 \mathrm{~m}^{3} \mathrm{~s}^{-1}$. RD values for this flow span the transition to strong flow retardation: $0.28(\mathrm{~L}), 0.43(\mathrm{M})$ and $0.22(\mathrm{R})$. Note the very strong flow differentiation between the three anabranches and their adjacent islands and floodplain.

between 200 and $400 \mathrm{~m}$. Because each anabranch in a cross section behaves essentially independently, flow geometry adjustments are analyzed separately for each channel. Bankfull levels were defined morphologically as the minimum $w / d$ (width/depth) channel geometry (i.e., usually the lowest bank), but in many cases a considerable difference in the height of either bank means that partial flow confinement continues beyond bankfull as defined by minimum $w / d$ geometry.

[18] Downstream hydraulic geometry was originally devised to examine the adjustment of flow variables (e.g., $w, d, v, s, \mathrm{ff}$ ) along and between single-thread streams at comparable discharge frequencies, usually at bankfull [Leopold and Maddock, 1953]. Taking the bankfull flow data from Table 4, a variant of hydraulic geometry was applied for anabranching rivers, as proposed by Tabata and Hickin [2003] where individual channels are compared at bankfull.

\subsection{At-Station Hydraulic Geometry: Results and Analyses}

[19] Between the 10 individual channels $Q_{b}$ varies widely from 4.6 to $21.0 \mathrm{~m}^{3} \mathrm{~s}^{-1}$, though when summed to a total discharge at each of the five stations the range narrows to 15-26 $\mathrm{m}^{3} \mathrm{~s}^{-1}$ (Table 4). Once flows overtop the banks, the proportion of overbank discharge grows in a consistent fashion at all five stations (Figure 2c). At a total discharge of $100 \mathrm{~m}^{3} \mathrm{~s}^{-1}$ approximately one third of the flow is conveyed overbank, growing to half at $210 \mathrm{~m}^{3} \mathrm{~s}^{-1}$ (i.e., equivalent to $\sim 4 \%$ and $\sim 1 \%$ flow duration, respectively) (Figure $2 \mathrm{a}$ ).

[20] For many of the hydraulic geometry scatterplots (Figure 3), power law functions fail to capture the variance in the data. It is not surprising that conventional functional relations fail here; they were originally derived from and are generally applied to flow data that do not extend much beyond bankfull whereas we present measurements on flows that are up to $15 Q_{b}$ (Table 3 ). In order to characterize the 


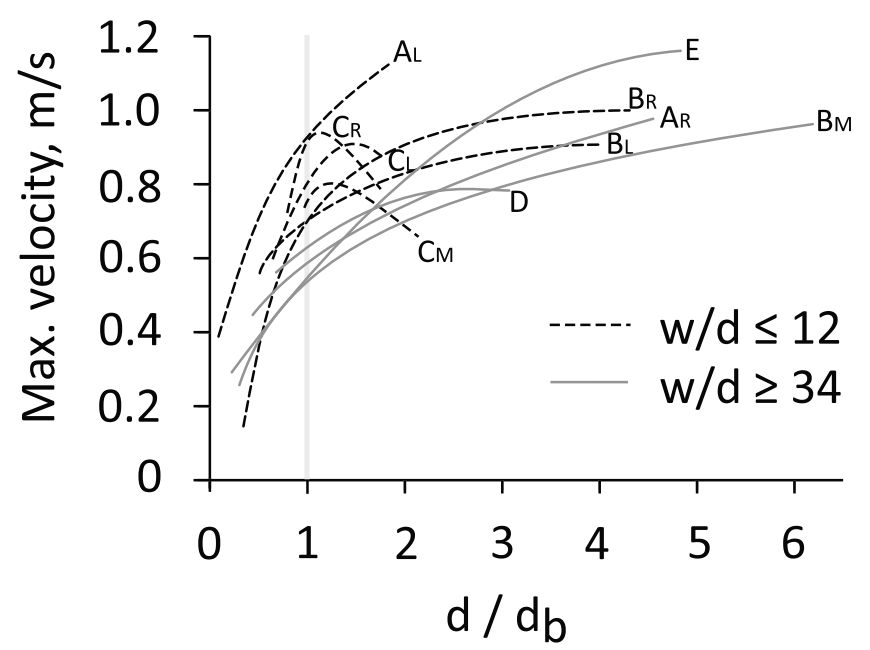

Figure 5. Maximum flow velocity (i.e., the highest overbed velocity measured in the cross section) versus $d / d_{b}$ (mean flow depth normalized to bankfull depth) for rated flows in each of the 10 channels (quadratic curves of best fit). Note that bankfull flow $\left(d / d_{b}=1\right)$ is denoted by the vertical shaded line, and several of the ratings were measured during floods that exceeded more than 4 times bankfull depth.

segmentation that occurs in some of the plots, the data are partitioned into subsets of $<Q_{b}$ and $>Q_{b}$ (and multiples of $Q_{b}$ in a couple of cases). Bankfull is defined by a discharge range in each channel (Figure 3) due to the variability in bank height, and for the purpose of the data partitioning $Q_{b}$ is taken as the minimum $w / d$ geometry. All regression parameters and correlation coefficients are listed (Table 3), and segmentation in the data is indicated by large differences in the power law exponents listed. The relations for channel width are not given because width cannot be defined when overbank flows mix across different anabranches.

[21] The flow depth data are generally well described by simple power law functions unlike mean flow velocity, which for several of the anabranching channels increases less rapidly for flows exceeding bankfull (XS-B, XS-D), with marked slow down at XS-C. Water-surface slope $(s)$ was measured at one of the triple-anabranching cross sections (XS-C) and at the two single channel cross sections (XS-D, XS-E). An increase in slope with discharge is observed in many rivers [e.g., Leopold and Maddock, 1953], but it seems that in Magela Creek slope for both the anabranching and single thread reaches adjusts to increasing discharge in complicated ways, somewhat unique to each individual channel (Figure 3).

[22] Flow resistance, as represented by the DarcyWeisbach friction factor (ff) is given by

$$
\mathrm{ff}=8 g r s / v^{2},
$$

where $g$ is the gravitational constant, $r$ is hydraulic radius, $s$ is water surface slope and $v$ is mean flow velocity. In many rivers, ff declines with discharge as elements responsible for bed roughness are overcome by deepening flows [Simons and Richardson, 1966]. However, the wide scatter suggests that ff (partly driven by slope $(s)$ in equation (2)), does not respond uniformly in Magela Creek (Figure 3); in fact, ff appears to increase with stage in several cases $\left(\mathrm{XS}-\mathrm{B}_{\mathrm{L}}, \mathrm{XS}-\mathrm{C}, \mathrm{XS}-\mathrm{E}\right)$. One explanation is that ff variations reflect local overbed and overbank roughness associated with spatial patterns of dense midstorey shrubs (e.g., Barringtonia sp. and Pandanus sp.).

[23] Relative depth plots (Figure 4a) describe overbedoverbank flow interactions in terms of mean overbed velocity, $V_{c}$ (i.e., mean velocity of water flowing above the channel bed including that below and above bankfull), relative to mean total velocity, $V_{t}$ (i.e., velocity of the full valley section), or mean bankfull velocity, $V_{b}$. Observations at all 10 channels extend to $R D>0.4$, and $R D \sim 0.8$ for five of these, and most channels have data for flows several times greater than bankfull (up to $15 Q_{b}$ ). High overbed velocity relative to total velocity $\left(V_{c} / V_{t}\right)$, such as for all three anabranches at XS-C (Figure 4a), indicates a marked difference between velocities in the channel compared to those over the adjacent floodplain (see also Figure 4b). Where $V_{c} / V_{t}$ drops sharply, as for deeper flows at XS-C, we interpret this to indicate momentum exchange due to eddy shedding, which drives down overbed velocities and increases floodplain velocities [cf. White and Nepf, 2008]. Except for the three XS-C anabranches, overbed velocity ratios $\left(V_{c} / V_{b}\right)$ increase nonlinearly to $\sim 1.5$ to 3.5 with increasing overbank depth. This seems unusual; data from flumes and other rivers typically show a decrease in $V_{c} / V_{b}$ due to momentum exchange as flows rise significantly overbank [e.g., Knight and Shiono, 1996; Knighton and Nanson, 2002; White and Nepf, 2008].

[24] Channel geometry is related in a complicated way to velocity trends with rising stage in Magela Creek. Significant mixing of overbed and overbank flows leads to declining values of $V_{c} / V_{t}$ with stage, but results from Magela Creek show that such interactions are suppressed until flow is well above bankfull. The ratio $V_{c} / V_{b}$ increases most clearly $(>2-3)$ in channels with high $w / d$ ratios and where overbed flow resistance declines with increasing stage; such sites include $\mathrm{XS}-\mathrm{A}_{\mathrm{R}}, \mathrm{XS}-\mathrm{B}_{\mathrm{M}}$, and XS-D (all with $w / d \geq 34$ ). In narrower, deeper channels, overbed-overbank interactions are much more pronounced and $V_{c} / V_{b}$ is suppressed or even declines. The XS-C anabranches $(w / d \leq 12)$ provide the best examples of strong decline in $V_{c} / V_{t}$ with stage, and further examples of strong overbed-overbank interactions also occur at XS- $\mathrm{A}_{\mathrm{L}}$, $\mathrm{XS}-\mathrm{B}_{\mathrm{L}}$, and $\mathrm{XS}-\mathrm{B}_{\mathrm{R}}$ where $w / d$ range from 8 to 11 . The Magela Creek channels vary widely but commonly show strong flow retardation beginning at overbank depths as low as $R D<0.3$ and reaching as high as $R D \sim 0.8$ (Figure $4 \mathrm{a}$ ). By contrast, flume experiments and some field measurements where $w / d \sim 10$, show maximum overbed-overbank interactions at $R D \sim 0.1-0.3$ [Knighton and Nanson, 2002; Knight and Shiono, 1996].

[25] From the at-station hydraulic geometry data, two distinct types of channel were identified based on $w / d$ ratio. In the first group, all with $w / d \leq 12\left(\mathrm{XS}-\mathrm{A}_{\mathrm{L}}, \mathrm{XS}-\mathrm{B}_{\mathrm{L}}, \mathrm{XS}-\mathrm{B}_{\mathrm{R}}\right.$, $\mathrm{XS}-\mathrm{C}_{\mathrm{L}}, \mathrm{XS}-\mathrm{C}_{\mathrm{M}}$, and $\mathrm{XS}-\mathrm{C}_{\mathrm{R}}$ ), fast-moving flow is "confined" over the channel bed to depths substantially above those defined by the height of the alluvial banks. These low $w / d$ channels attain a maximum velocity of $\sim 0.7-1.1 \mathrm{~m} \mathrm{~s}^{-1}$ at 1-2 times bankfull depth (Figure 5). At even higher discharges, overbed-overbank interactions magnify and this fast-flowing thread becomes disrupted causing $V_{c} / V_{t}$ ratios to flatten or even decline sharply (Figure $4 \mathrm{a}$ ). In contrast, the second group of channels $\left(X S-A_{R}, X S-B_{M}, X S-D\right.$, and 

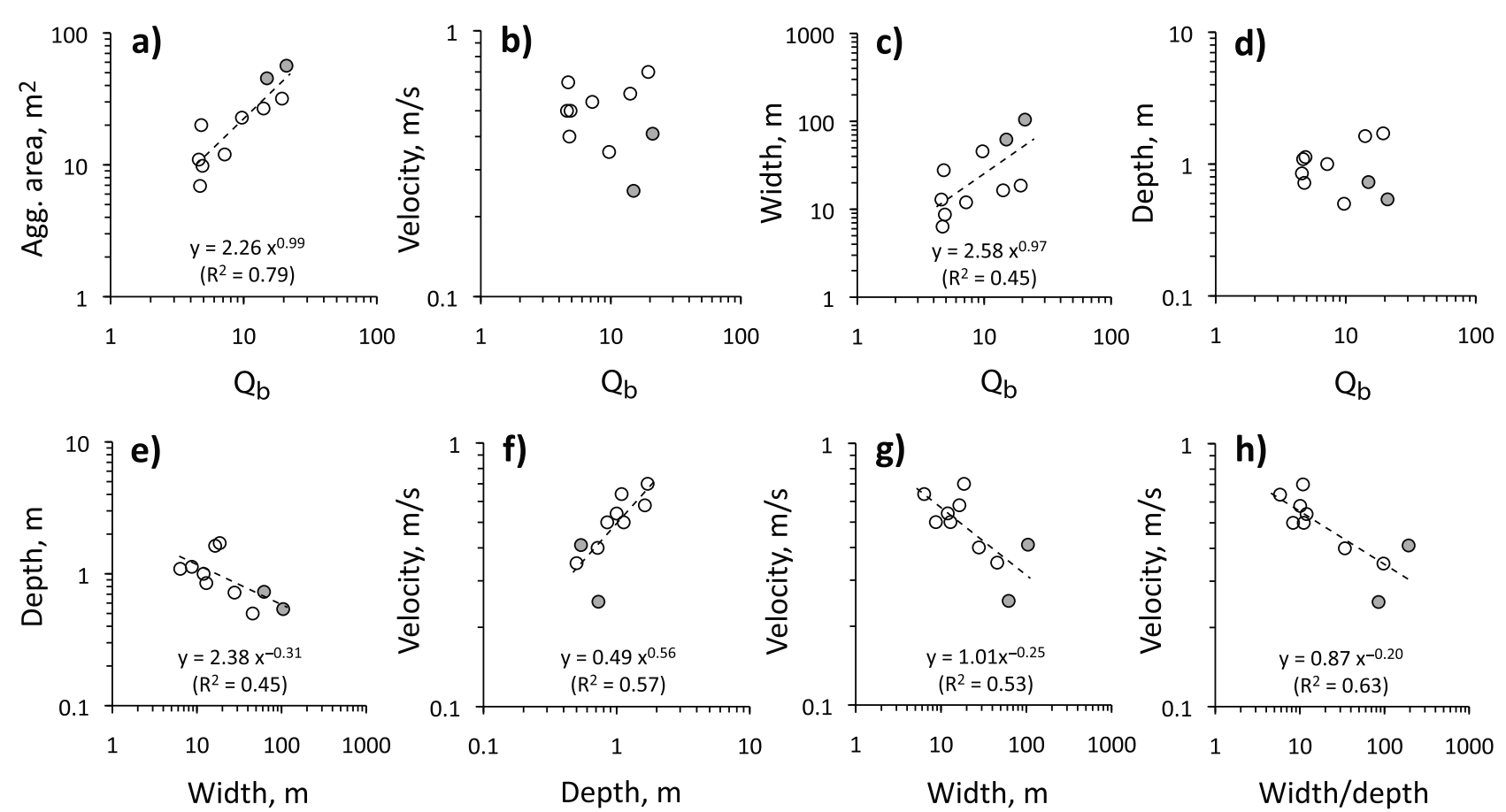

Figure 6. Interchannel hydraulic geometry for the 10 individual channels, with least squares regressions (all best fit curves are statistically significant at the $95 \%$ level, $p<0.05$ ). Single channels (XS-D, XS-E) are denoted by shaded circles. (a) Aggregated channel cross section area versus $Q_{b}$ (b) Mean overbed velocity versus $Q_{b}$. (c) Channel width versus $Q_{b}$. (d) Channel depth versus $Q_{b}$. (e) Channel depth versus channel width. (f) Mean overbed velocity versus channel depth. (g) Channel width versus mean overbed velocity. (h) Width/depth versus mean overbed velocity.

XS-E) has relatively wide, shallow sections $(w / d \geq 34)$, and because flow is not very effectively confined, velocity climbs more slowly, maximizing at the very highest discharges only when a great deal of water has escaped from the channels and is traveling overbank (Figures 4 and 5). The implications of these two distinctly different hydraulic geometries are addressed below.

\subsection{Interchannel Bankfull Hydraulic Geometry: Results and Analyses}

[26] Increasing bankfull discharge, $Q_{b}$, is accommodated via increases in cross-sectional area rather than any clear trend of increased velocity (Figures $6 \mathrm{a}$ and $6 \mathrm{~b}$ ), and the growth in cross-sectional area is achieved mainly by channel widening rather than deepening (Figures $6 \mathrm{c}$ and $6 \mathrm{~d}$ ). There is some tendency for channels to deepen as they narrow, but mean depth nowhere exceeds $\sim 2 \mathrm{~m}$ (Figure $6 \mathrm{e}$ ). Mean depth is a strong determinant of overbed velocity, although width is also a factor, such that channels with lowest $w / d$ ratio carry the swiftest flows (Figures $6 \mathrm{e}-6 \mathrm{~h}$ ). The limitation of bank height to $\sim 2.0 \mathrm{~m}$ suggests a bank strength constraint that likewise restricts overbed velocity (Figure 6f). Aggregating hydraulic geometry for each of the five cross sections shows how the anabranching system behaves as the number of channels increases (Table 4). The $w / d$ ratios clearly decline as the number of channels increases in a valley section (Figure 7a). Aggregated bed width and area show some tendency to both decline (Figures $7 \mathrm{~b}$ and $7 \mathrm{c}$ ), whereas velocity shows evidence of increasing with more channels (Figure 7d). Faster flow stems from the anabranches becoming deeper and narrower, thereby offering less flow resistance (see Figure 6h).

\section{Sediment Transport and Storage: Approach and Methods}

[27] Field measurements of bed load transport rate, $Q_{s}$, are coupled with modeled estimates at the five stations and then time integrated with the discharge frequency distribution at XS-D (Figure 2a) in order to estimate the annual sediment yield at each of the five stations, and to determine the effective sediment-transporting discharge increment that is responsible for transporting the most bed load over extended time, $Q_{e}$.

[28] Bed load transport was measured with a rod-mounted $76.2 \mathrm{~mm}$ Helley-Smith pressure difference sampler [Helley and Smith, 1971]. Under conditions of known discharge, velocity, and slope, Roberts [1991] collected 671 bed load samples over 22 floods at XS-C, and Jansen and Nanson [2004] collected 220 samples over 5 floods at XS-E. Bed load transport rate was calculated using the mean section method [Edwards and Glysson, 1998], and details of field methods are described in Jansen and Nanson [2004].

[29] Roberts [1991] compares his field measurements of $Q_{s}$ with the predictions of several bed load transport formulae and concludes that the van Rijn [1984] equations best characterize $Q_{s}$ in Magela Creek. The bed load transport equations of van Rijn [1984] derive from regression analysis 


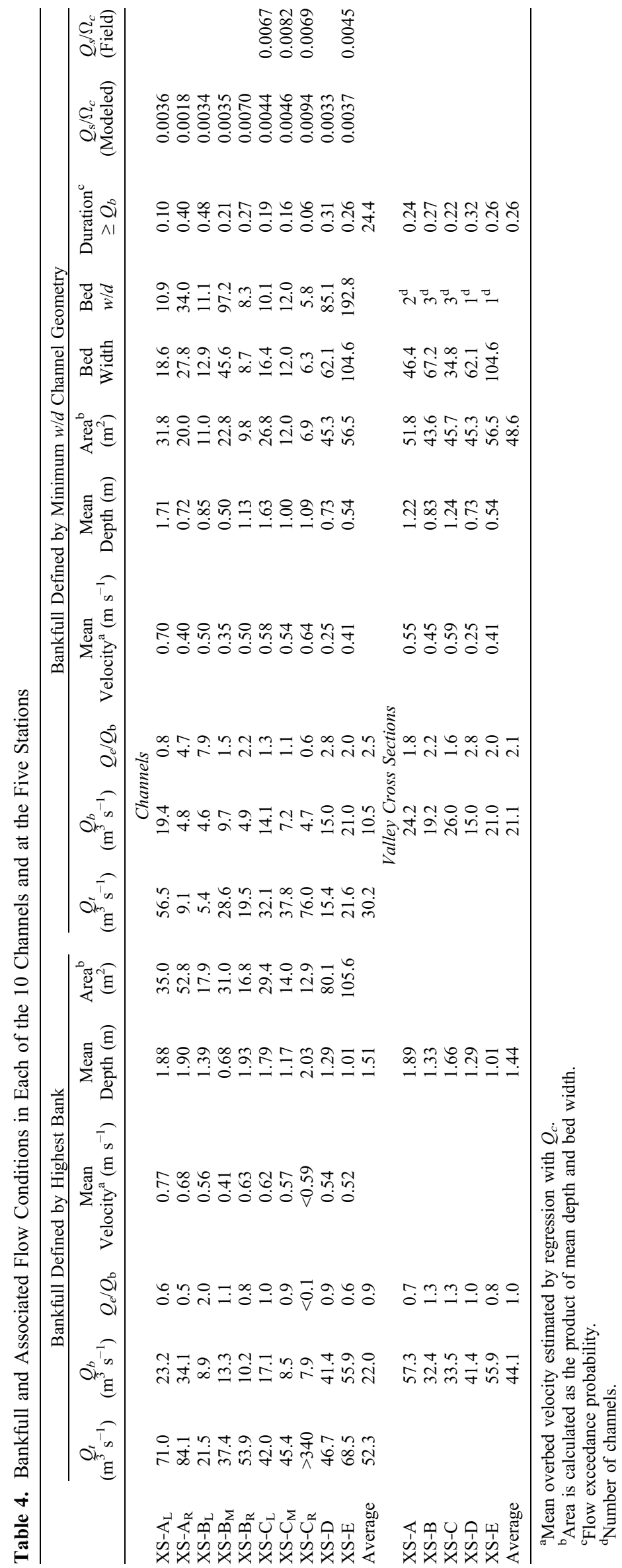

11 of 17 

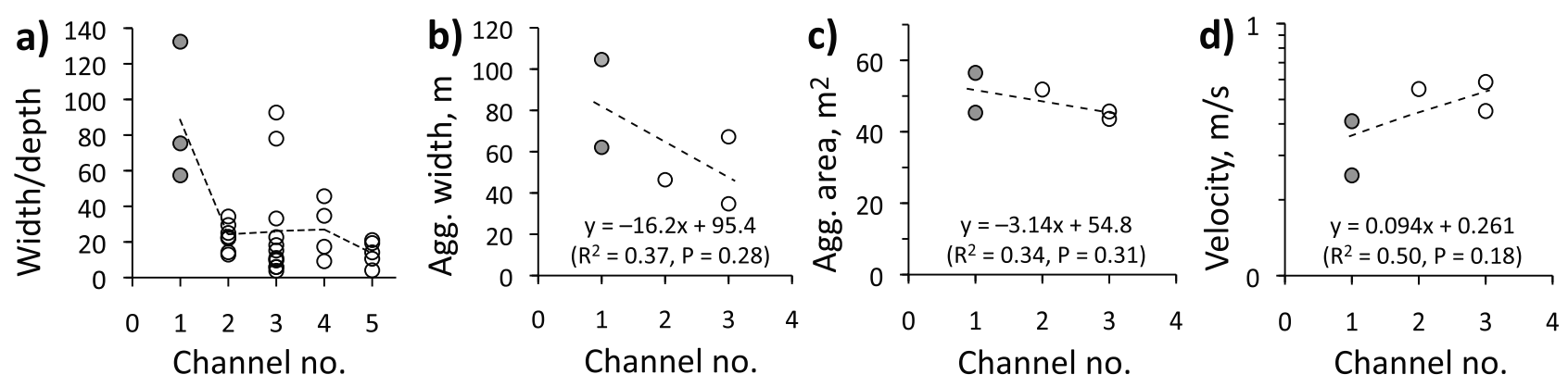

Figure 7. Interchannel hydraulic geometry (summed channel variables) as a function of the number of channels at the five stations (note that none of the linear regressions are statistically significant at the $95 \%$ level, $p<0.05$ ). (a) Width/depth versus number of channels from 13 cross sections in the study reach; the dashed line joins average $w / d$ values. (b) Aggregated channel width versus number of channels. (c) Aggregated cross-sectional area versus number of channels. (d) Velocity versus number of channels, where velocity is averaged across channels at each cross section.

of the relation between bed load transport rate and excess mean flow velocity, as given by

$$
q_{v b}=0.005 v d\left[\left(v-v_{c}\right) / \sqrt{\left(\rho_{s}-\rho / \rho\right)} g D_{50}\right]^{2.4}\left(D_{50} / d\right)^{1.2},
$$

where $v$ is mean flow velocity, $\rho_{s}$ is density of sediment, $\rho$ is density of water, $d_{x}$ is the grain diameter at which $x \%$ of the bed material is finer, $q_{v b}$ is the bed load transport rate in units of solid volume per unit width per unit time (applicable to sand transport in lower and transitional flow regimes), and $v_{c}$ is the critical mean flow velocity for grain motion, based on the Shields criterion and the logarithmic velocity profile (for $0.1 \leq D_{50} \leq 0.5 \mathrm{~mm}$ ) as

$$
v_{c}=0.19\left(D_{50}\right)^{0.1} \log \left(12 r / 3 D_{90}\right) \text {. }
$$

Finally, $q_{v b}$ converts to units of dry mass per unit width per unit time with the relation

$$
q_{B}=r_{s} q_{v b} .
$$

Comparing the model-predicted $Q_{s}$ with field-measured $Q_{s}$ at XS-C and XS-E, there is a $70 \%$ agreement within a factor of 2 (Figure 8).

[30] Flow efficiency is defined as maximum sediment transport capacity per unit available stream power, $Q_{s} / \Omega$ [Huang and Nanson, 2000; Huang et al., 2004; Nanson and Huang, 2008]. Following Jansen and Nanson [2004] flow efficiency is expressed as bed load transport rate per overbed power $\left(\Omega_{c}\right)$, where

$$
\Omega_{c}=\gamma Q_{c} s,
$$

in which $\gamma$ is the specific weight of water $\left(9807 \mathrm{~N} \mathrm{~m}^{-3}\right), Q_{c}$ is discharge conveyed above the channel bed, and $s$ is water surface slope.

\subsection{Sediment Transport and Storage: Results and Analyses}

[31] $Q_{s}$ is not generally a simple power function of discharge (Figure 9), though the $Q_{e}$ increment is consistent at $40-45 \mathrm{~m}^{3} \mathrm{~s}^{-1}$ across all 5 stations (Figure 10). The anabranching sites (XS-A, XS-B, XS-C) all show notably higher peak yields than the single channel sites (XS- XS-D, $\mathrm{XS}-\mathrm{E}$ ), and the broader $Q_{e}$ peak at XS-A suggests a wider range of flows $\left(\sim 40-70 \mathrm{~m}^{3} \mathrm{~s}^{-1}\right)$. Bed load yield derived from model predictions and field measurements declines downstream between XS-A and Madjinbardi Billabong (Figure 11). A linear regression fitted to the XS-A to XS-E data indicates that the decline in bed load yield amounts to storage of $1805 \pm 737 \mathrm{t} \mathrm{yr}^{-1}$ ( \pm regression slope standard error) along the $12.45 \mathrm{~km}$ reach between XS-A and XS-E, representing $\sim 29 \pm 12 \%$ bed material sequestration. To convert to an average vertical accretion rate, bed load yield data are integrated with the surface area that receives bed load, as only the bed load component of the total sediment yield contributes to the valley fill. The wash load and solutes are flushed downstream to Madjinbardi Billabong and beyond, possibly due to the flow's low kinematic viscosity that keeps the majority of the wash load overbed [Roberts, 1991]. Evenly spread, $1805 \pm 737 \mathrm{t} \mathrm{yr}^{-1}$ of bed material storage across $2.36 \times 10^{6} \mathrm{~m}^{2}$ of valley floor amounts to $0.76 \pm 0.31 \mathrm{~kg} \mathrm{~m}^{-2} \mathrm{yr}^{-1}$ and a vertical accre-

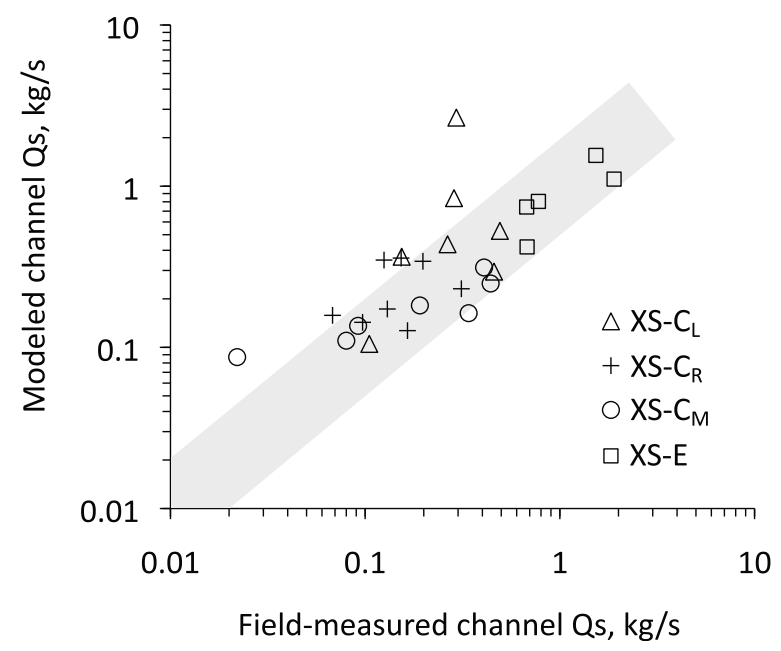

Figure 8. Field-measured $Q_{s}$ versus modeled $Q_{s}$ at XS-C and XS-E. The correspondence is satisfactory; $70 \%$ of the field measured and model-predicted results agree within a factor of 2 (shaded zone) and the standard error is 0.49 . 

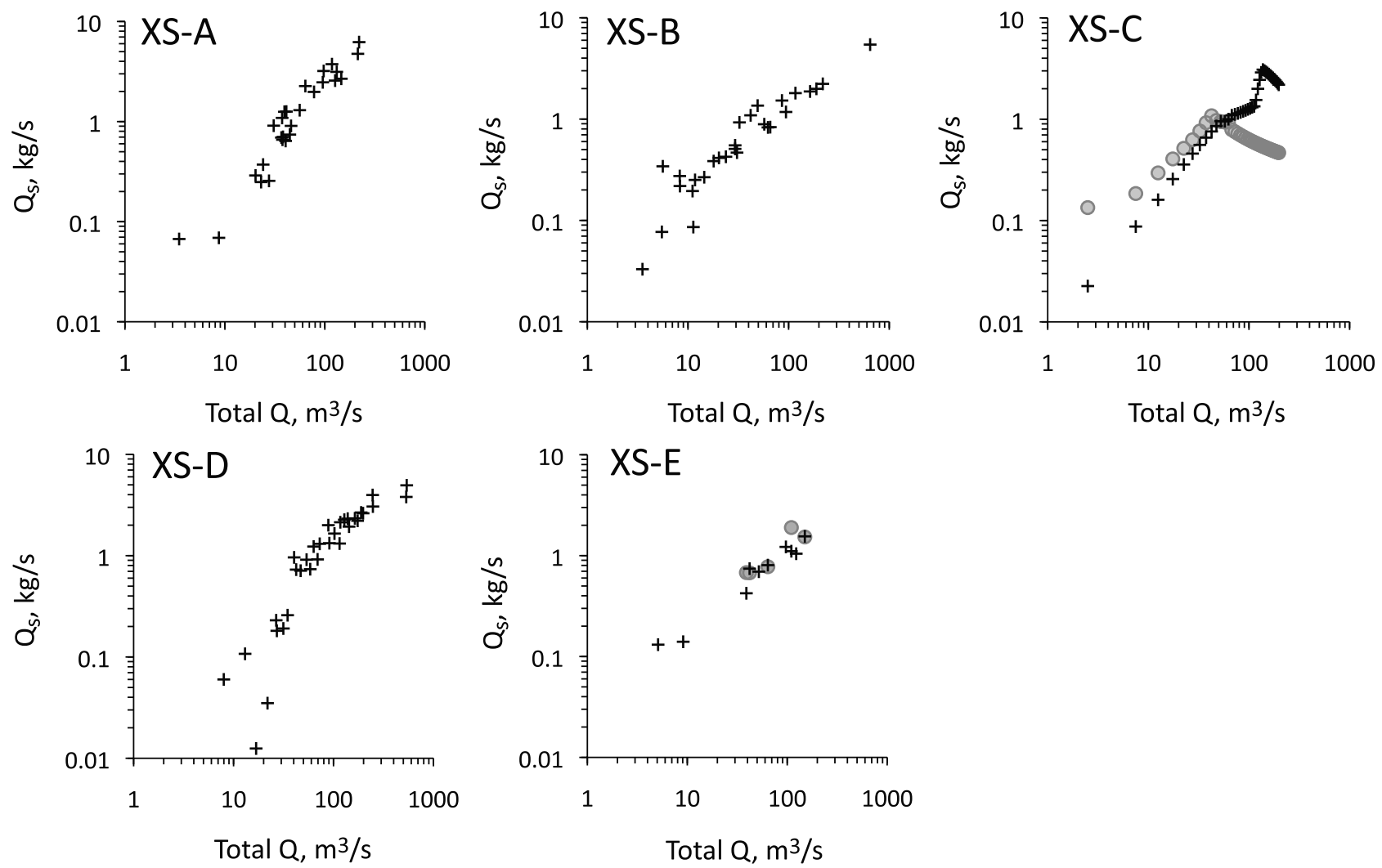

Figure 9. Bed load transport $\left(Q_{s}\right.$ in $\left.\mathrm{kg} \mathrm{s}^{-1}\right)$ rating data at the five stations. $Q_{s}$ data are derived from van Rijn's [1984] equations (black crosses) and field measurements (shaded circles). The lack of data scatter at $\mathrm{XS}-\mathrm{C}$ is the result of meshing three curves fitted to bed load data measured in each of the three anabranches, as collected by Roberts [1991].

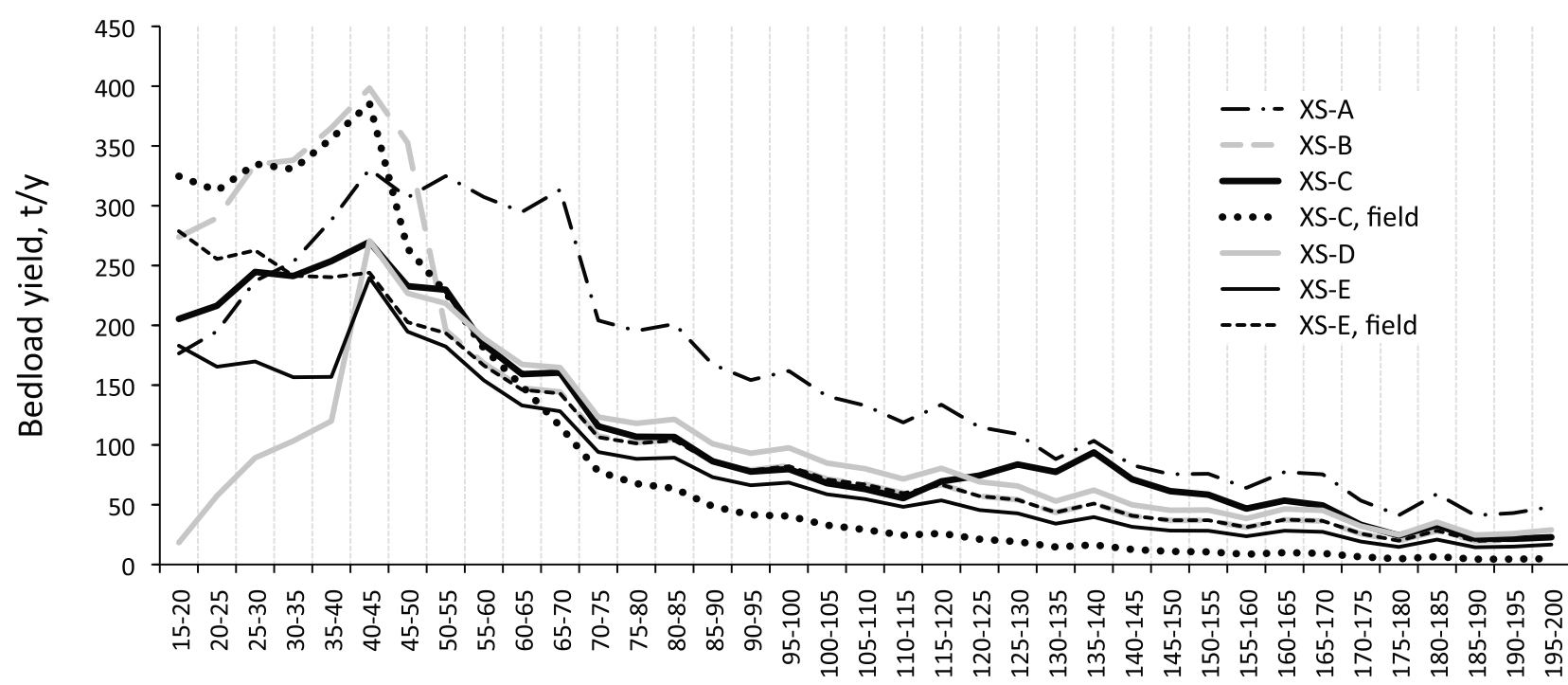

Total Q intervals, $\mathrm{m}^{3} / \mathrm{s}$

Figure 10. Bed load transport effectiveness curves from modeled and field-measured data. Each curve represents the estimated annual bed load yield $\left(\mathrm{t} \mathrm{yr}^{-1}\right)$ at the 5 stations for discharge increments 15 to $200 \mathrm{~m}^{3} \mathrm{~s}^{-1}$. The maximum point on each curve indicates the most effective sediment-transporting discharge $\left(Q_{e}\right)$, which is consistent at $40-45 \mathrm{~m}^{3} \mathrm{~s}^{-1}$ for all five stations. 


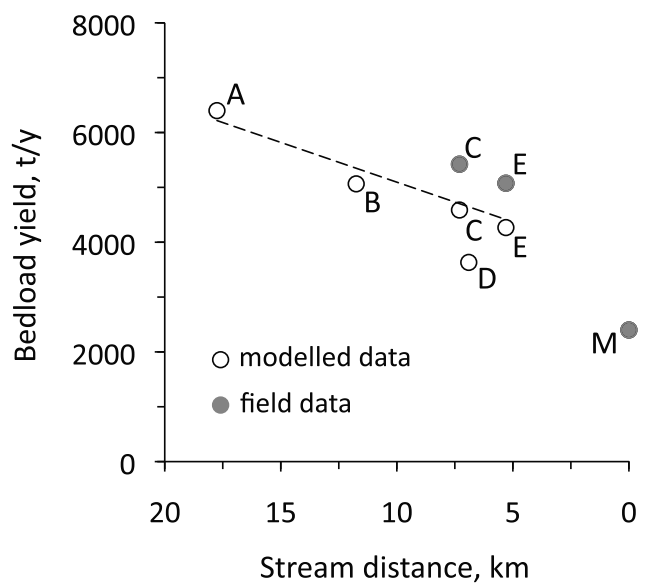

Figure 11. Model predicted and field-measured bed load yield versus stream distance (upstream from Madjinbardi Billabong, M); letters denote the XS. The linear regression, $y=145 x+3645\left(R^{2}=0.55\right.$; regression slope standard error $=59$ ) indicates a difference in bed load yield of $1805 \pm 737 \mathrm{t} \mathrm{yr}^{-1}$ between XS-A and XS-E, which we assume is stored. Note that these totals exclude the relatively minor amounts transported by discharges exceeding $200 \mathrm{~m}^{3} \mathrm{~s}^{-1}$, which explains the discrepancy between these data and the $5182 \mathrm{t} \mathrm{yr}^{-1}$ of bed load yield calculated by Roberts [1991]. The rate of delta growth at Madjinbardi Billabong (i.e., $1294 \pm 249 \mathrm{~m}^{3} \mathrm{yr}^{-1}$, for 1980-2002) provides an independent check against the model and field data. By assuming 30\% intergranular porosity, this volumetric growth rate converts to $2400 \pm 462 \mathrm{t} \mathrm{yr}^{-1}$, as plotted here.

tion rate of $0.41 \pm 0.17 \mathrm{~mm} \mathrm{yr}^{-1}$ (assuming sediment density of $2650 \mathrm{~kg} \mathrm{~m}^{-3}$ with $30 \%$ intergranular porosity).

[32] According to theoretical determinations by Huang and Nanson [2007], Magela Creek should exhibit maximum flow efficiency at the long-term maximum sedimenttransporting discharge. Notwithstanding some degree of scatter, all sites achieve peak flow efficiency at $40-45 \mathrm{~m}^{3} \mathrm{~s}^{-1}$ (Figure 10). Huang and Nanson [2007] also predict a close relationship between flow efficiency and channel $w / d$ ratio in anabranching rivers; a prediction that finds support in our data, which reveals high efficiencies for $w / d$ ratios $\leq 12$ and less efficient channels above this value (Figure 12). It is important to note that several studies in Canada do not support the proposal that anabranching rivers necessarily exhibit greater flow efficiencies [Abbado et al., 2009; Burge, 2005; Tabata and Hickin, 2003], which suggests that anabranching spans a spectrum of flow efficiencies, as discussed by Jansen and Nanson [2004].

\section{Discussion and Conclusions}

[33] Compared to many other closely studied rivers, Magela Creek has an unusual morphology; more than $92 \%$ of the alluvial tract above Madjinbardi Billabong is anabranching, and the data presented here describe hydraulic geometry that is unlike many rivers previously described. Perhaps most importantly, the sandy channel banks, islands, and floodplains support a vegetation cover that appears to foster a much wider variety of geometric adjustments than would occur otherwise. Our study attempts to quantify the observed interactions between river pattern, water and sediment fluxes, and the effects of riparian vegetation; namely, for increasing bank strength, raising flow drag, and restricting high velocity flow to a zone above the channel bed. We argue that these interactions result in stabilizing mechanisms that ensure the long-term stability of the channelfloodplain system.

[34] Bed load transport capacity is a key determinant of channel form and stability. Any imbalance in the relationship between supply and transport leads to channel instability via erosion or aggradation. In a stable river the interactions between channel planform and hydraulic geometry act to maintain conditions near to a mass flux balance [Nanson and Huang, 2008]. Based on evidence from a series of air photographs since the 1950s, the presence of mature stands of bank vegetation [Erskine, 2002], the considerable age of islands [2.3 to $3.4 \mathrm{kyr}$, Tooth et al., 2008], and the preliminary research by Jansen and Nanson [2004], the remarkable stability of Magela Creek was anticipated early in our study. Further evidence comes from the consistency in the magnitude and high frequency of the effective discharge (Figures $2 \mathrm{~b}$ and 10), and the relatively low rate of bed material sequestration leading to $\sim 0.41 \pm$ $0.17 \mathrm{~m} \mathrm{kyr}^{-1}$ of valley floor aggradation (Figure 11). Although the study reach is not in absolute mass flux balance, the long-term stability of the system suggests that $Q_{e} \approx Q_{d} \approx 40-45 \mathrm{~m}^{3} \mathrm{~s}^{-1}$. Interestingly, the contemporary accretion rate is considerably less than the $1-2 \mathrm{~m} \mathrm{kyr}^{-1}$ calculated for the past 3000 years [Nanson et al., 1993], possibly pointing to the anabranching channels becoming more efficient bed load conduits over time [Tooth et al., 2008]. Certainly, the anabranches have a higher longterm bed load transport capacity relative to single channels (Figure 10), and given the predominance of the anabranching pattern, we speculate that without it Magela Creek would slide into substantial mass flux disequilibrium and associated instability. We infer that single-channel

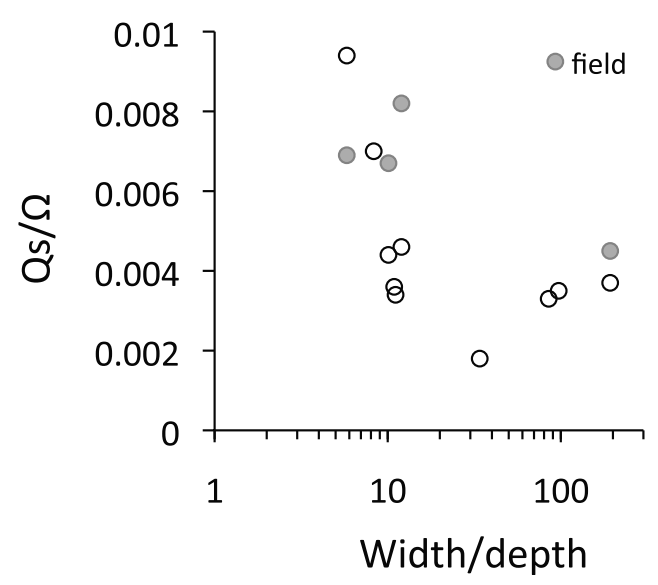

Figure 12. Flow efficiency versus width/depth at the effective discharge for all 10 channels (including field and modeled data). Flow efficiency is calculated as bed load transport rate $\left(Q_{s}\right.$, in units of $\left.\mathrm{kg} \mathrm{s}^{-1}\right)$ per overbed stream power $\left(\Omega_{c}\right.$, in units of $\mathrm{W} \mathrm{m}^{-1}$; equation (6)). 
reaches are rare because their comparative inefficiency renders them unstable and so prone to iterative shifts that favor the development of stable channels dividing around islands [Tooth et al., 2008]. The sparser bank vegetation and less developed root mat lining single channels promotes their inherent instability [Erskine, 2002].

[35] Tabata and Hickin [2003] show that anabranches in Columbia River spill overbank more frequently than adjoining single channels because they have on average $22 \%$ smaller cross-section areas. This combination of frequent overbank flooding and low bankfull capacity may be a fundamental attribute of anabranching rivers [Makaske, 2001; Nanson and Knighton, 1996]. In humid areas, anabranching systems spend long periods overbank, as, for example, $27 \%$ of the year on Solimões River [Mertes, 1994], 14\% on Magdalena River [Smith, 1986], and 12\% on Columbia River [Makaske, 2001]. In dry lands and wetdry tropics where ephemeral streams prevail, the overbank duration may not appear prolonged if expressed annually, but may be a high proportion of the time the river is actually flowing. Magela channels flow overbank for $3-26 \%$ of the year, or $6-48 \%$ of the actual flow duration (Table 4 ) because the creek is essentially dry for half the year.

[36] Sediment transport capacity in many rivers declines when flows go overbank [Ackers, 1992; Atabay et al., 2005; Barishnikov, 1967]. Discharge $Q_{e}$ is typically near bankfull in single-thread rivers, and several studies suggest a range of 0.8-1.3 for $Q_{e} / Q_{b}$ [Andrews and Nankervis, 1995; Emmett and Wolman, 2001; Nash, 1994]. By contrast for Magela Creek, $Q_{e} / Q_{b} \sim 2.1 \pm 0.5$ (Table 4). Such a ratio would make $Q_{e}$ a low-frequency event in many rivers, but the low bankfull capacity in Magela Creek, as in Columbia River [Tabata and Hickin, 2003], ensures long periods of overbank flow. Although $Q_{e}$ is well over bankfull, it has a recurrence frequency of $\sim 1.01$ years and occurs for $13-15 \%$ of the flow duration (Figures 2a and 2b), a very high frequency relative to bed load streams elsewhere (e.g., $0.4-3 \%$ in Yampa River, Colorado; Andrews [1980]). The demonstrated ability of these channels to operate over long periods at their most effective sediment-transporting discharge appears to be a function of two related properties, as illustrated by Erskine [2002]: Banks strengthened by the root mats of riparian trees; and dense colonnades of trees that confine high-velocity flows over the channel bed at stages well above that defined by the banks and over longer durations than for single channels (Figures 4 and 5). The result is a self-stabilizing configuration in which multiple, relatively small anabranches convey high velocity flows in low $w / d$ channels that transport bed load more efficiently than in the wider single channels (Figures 5, 7, and 12).

[37] An important consequence of the overbed-overbank flow interactions along anabranches is the provision of an inbuilt stabilizing mechanism that dissipates erosional energy at very high stages. The low $w / d(\leq 12)$ anabranching channels confine relatively fast flows up to depths well above bankfull (e.g., Figure 4b), but for even higher discharges, this fast-flowing zone becomes disrupted, causing $V_{c} / V_{t}$ ratios to flatten or even decline (Figure $4 \mathrm{a}$ ). In contrast, the relatively wide shallow channels $(w / d \geq 34)$ increase their velocity and bed load transport rate more slowly, maximizing at the very highest discharges only, by which time a great deal of water has escaped overbank (Figures 4 and 5). Both mechanisms act to minimize the erosive potential of large floods, but the anabranching channels that constitute most of Magela Creek are particularly transport efficient at the lower, and therefore more frequent, discharges.

[38] In addition to dissipating energy, vegetation provides a second stabilizing mechanism via bank reinforcement. For a given gradient, self-adjusting channels in unconsolidated alluvium will adjust their hydraulic geometry and planform in response to water and sediment input. Any such adjustments must also take account of bank erodibility, and for this reason channels tend to widen rather than deepen with increases in discharge and/or sediment load. The importance of bank strength in understanding river regime was recognized early [e.g., Blench, 1969], but then was largely ignored due to the difficulties involved with quantifying bank strength and the related influences of riparian vegetation. Recently, there has been new enthusiasm for understanding the role of banks in confining flows in self-adjusting rivers [e.g., Brooks and Brierley, 2002; Eaton and Giles, 2009; Eaton and Millar, 2004; Millar, 2000; Millar and Quick, 1993; Nanson and Huang, 2008; Tal et al., 2004; Tal and Paola, 2007]. Channel narrowing may coexist with increased flow velocity only where banks are reinforced, which in natural rivers requires vegetation.

[39] Bank strength imparted by tree roots is exceeded at a threshold related to the density and spatial arrangement of the root network [Abernethy and Rutherfurd, 2001]. As described in section 3.3, Erskine's [2002] erodibility tests find that compared to grass cover, root mats yield a small fraction of material when subject to hydraulic action. Assuming that in Magela Creek such an erosional threshold is closely approached at the highest observed channel bank, $\sim 2.0 \mathrm{~m}$ (Figures $6 \mathrm{~d}$ and $6 \mathrm{e}$ ), this may represent the maximum stable bank height for the type of riparian vegetation found in this almost completely sand-dominated system [Erskine, 2002]. A maximum bank height set by riparian vegetation has direct implications for channel $w / d$ ratio, which as discussed above is central to the bed load transport efficiency of anabranching channels. Nonetheless, where riparian trees effectively confine overbed flows above the height of the bank, workers should beware of overemphasizing a bankfull optimum defined by the sediment bank height only. The more important issue is flow and sediment flux continuity and, as shown here, bank vegetation can hold high velocity flows over the channel bed up to stages well above that defined by the banks before significant flow is shed from the channel zone.

[40] Contrary to findings from Columbia River [Abbado et al., 2009; Tabata and Hickin, 2003] and several rivers in New Brunswick [Burge, 2005], flow efficiency and mean flow velocity through Magela Creek anabranches exceeds that for single-thread channels, resulting in higher rates of bed load transport at the effective discharge. Work on Magela Creek shows that some relatively inefficient anabranches can also form with $w / d$ ratios more comparable to single channels, just as described from Columbia River. However, one relatively narrow and deep, and hence particularly efficient, anabranch can be sufficient to transport nearly all the sediment load supplied to a reach, leaving ancillary anabranches to simply convey excess flow or progressively store bed material as they atrophy. 
[41] The anabranching style of Magela Creek would not exist without the biogeomorphological adjustment of riparian vegetation to stabilize channels, islands, and floodplains. The high flow efficiency (i.e., bed load transport rate to stream power ratio) of the anabranches at the effective discharge is facilitated by low width/depth channels with banks reinforced by vegetation. By contrast, the relative scarcity of single-channel reaches seems to be a function of their sparsely vegetated banks [Erskine, 2002], which makes them less stable, and incapable of developing the high-velocity threads, because flow is dispersed overbank (Figure 5). Bank vegetation has the capacity to stabilize even sand-dominated systems, such as Magela Creek, via colonnades of trees that simulate a "vegetation-walled corridor" that acts initially to impede momentum exchange between fast overbed flows and any water that escapes overbank. Eventually, at high flows, momentum exchange occurs between flow in the channels and that on the forested floodplains, limiting erosion and maintaining channel stability at flow depths that are 6 times bankfull, and discharges that are 15 times bankfull.

[42] Acknowledgments. This work was supported by a U. K. Natural Environment Research Council Research Fellowship (NE/EO14143/1) to J.D.J. and an Australian Research Council Large Grant (A00103535) to G.C.N. We thank the Environmental Research Institute of the Supervising Scientist (Darwin) for logistical support; E. Kerle (Northern Territory Lands, Planning and Environment) and R. Masters (Energy Resources Australia) for access to flow data; L. Erskine, L.M. Gibbs, and S. Tooth for field assistance and discussion; and P. A. Carling, M. Church, S. Darby, J. Pitlick, and two anonymous reviewers for exceptionally helpful critiques. We acknowledge the Traditional Owners of this country.

\section{References}

Abbado, D., R. Slingerland, and N. D. Smith (2009), Origin of anastomosis in the upper Columbia River, British Columbia, Canada, in Fluvial Sedimentology VII, edited by M. D. Blum, S. B. Marriott, and S F. Leclair, Spec. Publ. Int. Assoc. Sedimentol., 35, 1-15, doi:10.1002/ 9781444304350.ch1.

Abernethy, B., and I. D. Rutherfurd (2001), The distribution and strength of riparian tree roots in relation to riverbank reinforcement, Hydrol. Processes, 15, 63-79.

Ackers, P. (1992), Gerald Lacey memorial lecture canal and river regime in theory and practice: 1929-1992, Proc. ICE Water Mar. Energy, 96 , 167-178, doi:10.1680/iwtme.1992.21084.

Andrews, E. D. (1980), Effective and bankfull discharges of streams in the Yampa River basin, Colorado and Wyoming, J. Hydrol., 46, 311-330.

Andrews, E. D., and J. M. Nankervis (1995), Effective discharge and the design of channel maintenance flows for gravel-bed rivers, in Natural and Anthropogenic Influences in Fluvial Geomorphology, Geophys. Monogr. Ser., vol. 89, edited by J. E. Costa et al., pp. 151-164, AGU, Washington, D. C.

Atabay, S., D. W. Knight, and G. Seçkin (2005), The effects of overbank flow on fluvial sediment transport rates, Proc. ICE Water Manage., 158 , 25-34.

Barishnikov, N. B. (1967), Sediment transportation in river channels with flood plains, Int. Assoc. Sci. Hydrol. Publ., 75, 404-412.

Bates, R. L., and J. A. Jackson (1987), Glossary of Geology, 3rd ed., Elsevier, New York.

Blench, T. (1969), Mobile Bed Fluviology, 2nd ed., 164 pp., Uni. of Alberta Press, Edmonton, Alberta, Canada.

Brooks, A. P, and G. J. Brierley (2002), Mediated equilibrium: The influence of riparian vegetation and wood on the long-term evolution and behaviour of a near pristine river, Earth Surf. Processes Landforms, 27, 343-367, doi:10.1002/esp.332.

Brown, A. G. (2002), Learning from the past: Palaeohydrology and palaeoecology, Freshwater Biol., 47, 817-829, doi:10.1046/j.13652427.2002.00907.x.

Burge, L. M. (2005), Wandering Miramichi rivers, New Brunswick, Canada, Geomorphology, 69, 253-274, doi:10.1016/j.geomorph.2005.01.010.
Collins, B. D., D. R. Montgomery, and A. D. Haas (2002), Historical changes in the distribution and functions of large wood in Puget lowland rivers, Can. J. Fish. Aquat. Sci., 59, 66-76.

Eaton, B. C, and T. R. Giles (2009), Assessing the effect of vegetationrelated bank strength on channel morphology and stability in gravelbed streams using numerical models, Earth Surf. Processes Landforms, 34, 712-724, doi:10.1002/esp. 1768 .

Eaton, B. C, and R. G. Millar (2004), Optimal alluvial channel width under a bank stability constraint, Geomorphology, 62, 35-45, doi:10.1016/j. geomorph.2004.02.003.

Edwards, T. K., and G. D. Glysson (1998), Field methods for measurement of fluvial sediment, U.S. Geol. Surv. Tech. Water Resour. Invest., Book 3, Chap. C2.

Emmett, W. W. (1980), Bed load sampling in rivers, in Proceedings of the International Symposium on River Sedimentation, pp. 991-1014, Guanghu Press, Beijing.

Emmett, W. W., and M. G. Wolman (2001), Effective discharge and gravel-bed rivers, Earth Surf. Processes Landforms, 26, 1367-1368.

Erskine, L. (2002), The relationship between riparian vegetation, bank erosion, and channel pattern, Magela Creek, Northern Territory, B.Sc. thesis, Univ. of Wollongong, Wollongong, N. S. W., Australia.

Fielding, C. R., J. Alexander, and E. Newman-Sutherland (1997), Preservation of in situ, arborescent vegetation and fluvial bar construction in the Burdekin River of north Queensland, Australia, Palaeogeogr. Palaeoclimatol. Palaeoecol., 135, 123-144.

Gregory, K. J., and D. E. Walling (1973), Drainage Basin Form and Process: A Geomorphological Approach, 456 pp, Edward Arnold, London.

Hart, B. T., E. M. Ottaway, and N. B. Noller (1987), Magela Creek system, northern Australia: I, 1982-1983 wet season water quality, Aust. J. Mar. Freshwater Res., 38, 261-288.

Harwood, K., and A. G. Brown (1993), Fluvial processes in a forested anastomosing river: Flood partitioning and changing flow patterns, Earth Surf. Processes Landforms, 18, 741-748, doi:10.1002/esp.329018080

Helley, E. J., and W. Smith (1971), Development and calibration of a pressure difference bedload sampler, U.S. Geol. Surv. Open File Rep., 73-108, 18 pp.

Herget, J. (2000), Holocene development of the River Lippe Valley, Germany: A case study of anthropogenic influence, Earth Surf. Processes Landforms, 25, 293-305.

Huang, H. Q., and G. C. Nanson (2000), Hydraulic geometry and maximum flow efficiency as products of the principle of least action, Earth Surf. Processes Landforms, 25, 1-13.

Huang, H. Q., and G. C. Nanson (2007), Why some alluvial rivers develop an anabranching pattern, Water Resour. Res., 43, W07441, doi:10.1029/ 2006WR005223.

Huang, H. Q., H. H. Chang, and G. C. Nanson (2004), Minimum energy as the general form of critical flow and maximum flow efficiency and for explaining variations in river channel pattern, Water Resour. Res., 40, W04502, doi:10.1029/2003WR002539.

Hupp, C. R., and W. R. Osterkamp (1996), Riparian vegetation and fluvial geomorphic processes, Geomorphology, 14, 277-295.

Jansen, J. D., and G. C. Nanson (2003), Sedimentation rates at Madjinbardi Billabong (1980-2002), Report for Kakadu National Parks Research Permit 560, 2 pp., Parks Aust., Darwin, N. W. T., Australia.

Jansen, J. D., and G. C. Nanson (2004), Anabranching and maximum flow efficiency in Magela Creek, northern Australia, Water Resour. Res., 40, W04503, doi:10.1029/2003WR002408.

Knight, D. W., and J. D. Demetriou (1983), Floodplain and main channel flow interaction, J. Hydraul. Eng., 109, 1073-1091.

Knight, D. W., and K. Shiono (1996), River channel and floodplain hydraulics, in Floodplain Processes, edited by M. G. Anderson, D.E. Walling, and P. D. Bates, pp. 139-181, John Wiley, New York.

Knighton, A. D., and G. C. Nanson (1993), Anastomosis and the continuum of channel pattern, Earth Surf. Processes Landforms, 18, 613-625.

Knighton, A. D., and G. C. Nanson (2002), Inbank and overbank velocity conditions in an arid zone anastomosing river, Hydrol. Processes, 16, 1771-1791, doi:10.1002/hyp.1076.

Latrubesse, E. M. (2008), Patterns of anabranching channels: The ultimate end-member adjustment of mega rivers, Geomorphology, 101, 130-145, doi:10.1016/j.geomorph.2008.05.035.

Leopold, L. B., and T. J. Maddock (1953), The hydraulic geometry of stream channels and some physiographic implications, U.S. Geol. Surv. Prof. Pap., 252.

Makaske, B. (2001), Anastomosing rivers: A review of their classification, origin, and sedimentary products, Earth Sci. Rev., 53, 149-196.

Makaske, B., D. G. Smith, and H. J. A. Berendsen (2002), Avulsions, channel evolution, and floodplain sedimentation rates of the anastomosing 
upper Columbia River, British Columbia, Canada, Sedimentology, 49 , 1049-1071, doi:10.1046/j.1365-3091.2002.00489.x.

Mertes, L. A. K. (1994), Rates of flood-plain sedimentation on the central Amazon River, Geology, 22, 171-174.

Millar, R. G. (2000), Influence of bank vegetation on alluvial channel patterns, Water Resour. Res., 36, 1109-1118.

Millar, R. G, and M. C. Quick (1993), Effect of bank stability on geometry of gravel rivers, J. Hydraul. Eng., 119, 1343-1363.

Nanson, G. C., and H. Q. Huang (2008), Least action principle, equilibrium states, iterative adjustment, and the stability of alluvial channels, Earth Surf. Processes Landforms, 33, 923-942, doi:10.1002/esp.1584.

Nanson, G. C., and A. D. Knighton (1996), Anabranching rivers: Their cause, character, and classification, Earth Surf. Processes Landforms, 21, 217-239.

Nanson, G. C., T. J. East, and R. G. Roberts (1993), Quaternary stratigraphy, geochronology, and evolution of the Magela Creek catchment in the monsoon tropics of northern Australia, Sediment. Geol., 83 , 277-302.

Nash, D. B. (1994), Effective sediment-transporting discharge from magnitude-frequency analysis, J. Geol., 102, 79-95.

Needham, R. S. (1988), Geology of the Alligator Rivers Uranium Field, N. T., Bur. Min. Resour. Geol. Geophys. Bull., 224.

Pickup, G., and R. F. Warner (1976), Effects of hydrologic regime on magnitude and frequency of dominant discharge, J. Hydrol., 29, 51-75.

Pišút, P. (2002), Channel evolution of the pre-channelised Danube River in Bratislava, Slovakia (1712-1886), Earth Surf. Processes Landforms, 27, 369-390, doi:10.1002/esp.333.

Richards, K. S. (1999), The magnitude-frequency concept in fluvial geomorphology: A component of a degenerating research programme?, Z. Geomorphol., 115, 1-18.

Roberts, R. G. (1991), Sediment budgets and Quaternary history of the Magela Creek catchment, tropical northern Australia, Ph.D. thesis, Univ. of Wollongong, Wollongong, N. S. W., Australia.

Simons, D. B., and E. V. Richardson (1966), Resistance to flow in alluvial channels, U.S. Geol. Surv. Prof. Pap., 422J.

Smith, D. G. (1986), Anastomosing river deposits, sedimentation rates, and basin subsidence, Magdalena River, northwestern Colombia, South America, Sediment. Geol., 46, 177-196.

Story, R. (1976), Vegetation of the Alligators Rivers area, Land Res. Ser., $38,89-111$.

Tabata, K. K., and E. J. Hickin (2003), Intrachannel hydraulic geometry and hydraulic efficiency of the anastomosing Columbia river, southeast- ern British Columbia, Canada, Earth Surf. Processes Landforms, 28 , 837-852, doi:10.1002/esp.497.

Tal, M., and C. Paola (2007), Dynamic single-thread channels maintained by the interaction of flow and vegetation, Geology, 35, 347-350, doi:10.1130/G23260A.1.

Tal, M., K. Gran, A. B. Murray, C. Paola, and D. M. Hicks (2004), Riparian vegetation as a primary control on channel characteristics in multithread rivers, in Riparian Vegetation and Fluvial Geomorphology, Water Sci. Appl. Ser., vol. 8, edited by S. J. Bennett, and A. Simon, pp. 43-58, AGU, Washington, D. C.

Tooth, S., and G. C. Nanson (2000), The role of vegetation in the formation of anabranching channels in an ephemeral river, Northern Plains, arid central Australia, Hydrol. Processes, 14, 3099-3117.

Tooth, S., and G. C. Nanson (2004), Forms and processes of two highly contrasting rivers in arid central Australia, and the implications fo channel pattern discrimination and prediction, Geol. Soc. Am. Bull. 116, 802-816, doi:10.1130/B25308.1.

Tooth, S., J. D. Jansen, G. C. Nanson, T. J Coulthard, and T. Pietsch (2008), Riparian vegetation and the late Holocene development of an anabranching river, Magela Creek, northern Australia, Geol. Soc. Am. Bull., 120, 1021-1035. doi:10.1130/B26165.1.

van Rijn, L. C. (1984), Sediment transport, part I, bed load transport, J. Hydraul. Eng., 110, 1431-1456.

Wasson, R. J. (Ed.) (1992), Modern Sedimentation and Late Quaternary Evolution of the Magela Creek Plain, Res. Rep. 6, 322 pp., Aust. Gov. Publ. Serv., Canberra, Aust.

Wende, R., and G. C. Nanson (1998), Anabranching rivers: Ridge-forming alluvial channels in tropical northern Australia, Geomorphology, 22 , 205-224.

White, B. L., and H. M. Nepf (2008), A vortex-based model of velocity and shear stress in a partially vegetated shallow channel, Water Resour. Res., 44, W01412, doi:10.1029/2006WR005651.

Wolman, M. G., and J. P. Miller (1960), Magnitude and frequency of forces in geomorphic processes, J. Geol., 68, 54-74.

J. D. Jansen, Department of Physical Geography and Quaternary Geology, Stockholm University, Stockholm, SE-106 91, Sweden. (john.jansen@natgeo.su.se)

G. C. Nanson, School of Earth and Environmental Sciences, University of Wollongong, Wollongong, NSW 2522, Australia. (gnanson@uow.edu.au) 